CEP Discussion Paper No 623

March 2004

\title{
Do Friends and Relatives Really Help in Getting a Good Job?
}

\author{
Michele Pellizzari
}




\begin{abstract}
Informal contacts are extensively used by both firms and workers to find jobs and fill vacancies. The common wisdom in the economic literature is that jobs created through this channel are of better quality and pay higher wages than jobs created through formal methods. This paper explores the empirical evidence for European countries using the European Community Household Panel (ECHP) and discovers a large cross-country as well as cross-industry variation in the wage differentials between jobs found through informal and formal methods. Across countries and industries wage premiums and wage penalties to finding jobs through personal contacts are equally frequent. This paper argues that such variation can be explained by looking at firms' recruitment strategies. In labour markets where employers invest largely in formal recruitment activities, matches created through this channel are likely to be of average better quality than those created through informal networks. A simple theoretical model is used to show that employers invest more in recruitment for high productivity jobs and for positions that require considerable training. The empirical predictions of the theory are successfully tested using industry-level data on recruitment costs.
\end{abstract}

JEL Classification: J31, J64, M51

Keywords: Social Networks, Wage Differentials, Recruitment, Hiring

This paper was produced as part of the Centre's Labour Markets Programme.

The Centre for Economic Performance is financed by the Economic and Social Research Council.

\title{
Acknowledgements
}

I would like to thank Alan Manning, Barbara Petrongolo and Steve Pischke and all participants to he CEP/LSE PhD Labour Market Workshops for useful comments and suggestions. I also greatly benefitted from discussions with Tito Boeri, Pietro Garibaldi, Jan Van Ours, Samuel Bentolila, Marco Leonardi, Federico Perali and Javier Ortega. Financial support from the ESRC, Bocconi University and University of Verona is gratefully acknowledged. All errors are my own responsibility.

Contact address: m.pellizzari@1se.ac.uk

Published by

Centre for Economic Performance

London School of Economics and Political Science

Houghton Street

London WC2A $2 \mathrm{AE}$

All rights reserved. No part of this publication may be reproduced, stored in a retrieval system or transmitted in any form or by any means without the prior permission in writing of the publisher nor be issued to the public or circulated in any form other than that in which it is published.

Requests for permission to reproduce any article or part of the Working Paper should be sent to the editor at the above address.

(C) Michele Pellizzari, submitted 2004

ISBN 0753017253 


\section{Introduction}

Informal contacts are extensively used by both firms and workers to find jobs and fill vacancies. Figure 1 shows the distribution of job finding methods for employed workers in European countries and the United States, and documents that, together with direct application and answering/placing advertisement, personal contacts are among the most important channels that lead people into jobs.

The importance of informal networks in the labour market is a known fact and has motivated a number of studies. Findings suggest that, compared to formal methods, informal contacts are a better channel to transmit information between job applicants and potential employers and should therefore lead to matches of better quality that pay higher wages. Some empirical evidence, mainly for the United States, supports this view and has contributed to make it the common wisdom among economists.

This paper produces new estimates for EU countries and discovers a large cross-country as well as cross-industry variation in the wage premiums paid to jobs found through informal networks. The data come from the European Community Household Panel (ECHP), a panel of European households, comparable across countries, where employed workers are asked to indicate the search channel through which they have found their current job. For the sake of comparison data for the United States are also included in the analysis ${ }^{1}$.

My best estimates indicate that informal search channels lead to significantly better paying jobs in Austria, Belgium and the Netherlands, while the opposite is true in Greece, Italy, Portugal and the United Kingdom. In the other EU countries - and in the US - no significant wage difference is observed. A even larger variation emerges from the cross-industry analysis. None of the 9 broad sectors considered shows differentials of the same sign in all countries. Moreover, only in 5 countries (Austria, Finland, Greece, Italy and United Kingdom) out of 15 the effects consistently point towards the existence of either a wage premium or a wage penalty to finding a job through personal contacts. In all other countries, informal search methods lead to significantly better paying jobs only in some sectors, while the opposite is true in others.

This paper aims at providing an explanation for the variation in wage differentials between jobs found through formal and informal channels. In doing this I take a rather unconventional approach in this branch of the literature. Most of the existing articles attempt to describe either the formation or the characteristics

\footnotetext{
${ }^{1}$ Although the sample is not fully comparable to the ECHP. See section 2.1 .
} 
of social networks and, on this ground, draw conclusions about the quality of the information that such networks are able to vehicle. This paper argues that a lot of the observed variation in wage differentials can be explained by variation in formal recruitment policies. In deciding their investment in recruitment, firms trade off the costs of a more intensive screening with the benefits of a more accurately selected workforce. This decision is obviously affected by the prevailing labour market conditions and is supposedly a very important factor in determining the ability of firms in selecting workers through formal recruitment methods relative to informal ones.

Specifically, the model that will be presented later, assumes that employers optimally choose their "formal recruitment effort": choose in how many newspapers and for how long to post a vacancy, decide how long and tough the interviewing process should be, buy and administer aptitudinal tests, choose the interviewers, etc. This allows to control the amount and the quality of the information that can be extracted from job applicants. The model shows that firms invest more in formal recruitment for high productivity jobs and positions that require considerable training. High productivity implies that the cost of hiring an unsuitable worker is higher, both in terms of forgone profits and wages, thus employers are induced to put more effort in selecting an appropriate candidate. High training costs also induce more recruitment effort in order to avoid bearing them again in the future, if the hire turns out to be unfit for the job. Formal recruitment for these types of positions is therefore likely to be more efficient than informal methods. This mechanism generates variation in the average quality of matches created through different channels and, in turn, leads to variation in wages.

The predictions of the model are tested using industry-level data on recruitment and training costs in selected EU countries ${ }^{2}$. Results confirm that the wage premium paid to jobs found through informal networks is indeed lower in industries in which firms invest more in recruitment, in high productivity jobs and positions that require training. Other empirical predictions of the model are also supported by the data.

Given their extensive use, informal networks must be an important factor in determining the overall efficiency of the matching process and this is already a sufficient motivation for studying the characteristics of jobs created through this channel. Moreover, by looking at firm's recruitment strategies, this paper touches upon a field that has received surprisingly little attention by economists. While the search behaviour of both the employed and the unemployed has been extensively studied, very little is known about

\footnotetext{
${ }^{2}$ See section 2.2 for a detailed description of these data.
} 
how firms look for workers. Finally, a better understanding of the role of informal networks would shed light on other unsolved issues like the sources of wage inequality and the functioning of social capital at the micro level.

Several papers have already investigated the role of informal networks in the labour market, mostly addressing two broad questions. The first one concerns the relative efficiency of search methods: are informal networks an efficient channel to find a job? Most microdata surveys contain questions about the search methods used by both employed and unemployed workers and a few papers (Holzer (1987b, 1988), Lindeboom et al. (1994), Osberg (1993)) have exploited this information to look at the relative efficiency of formal versus informal search. Findings indicate that those who rely on personal contacts normally receive more offers and find employment more quickly, thus suggesting that informal search is indeed a very efficient way to get a job.

The second question relates to the type of jobs that are found through informal networks: are these good or bad jobs? Do they pay higher or lower wages than similar jobs found via formal methods? There seems to be a generalised wisdom in the literature that these should actually be better jobs. A number of papers provide convincing explanations to support this wisdom. For example, Montgomery (1991) argues that, as people tend to have social ties with similar persons, employers can proxy the unobserved characteristics of applicants with those of their referees, about whom they have better information because, for instance, they have already worked at the firm for some time. Other authors (Kugler (2003), Saloner (1985)) suggest that employed contacts of unemployed workers tend to refer only good applicants because their reputation is at stake and, consequently, less able workers will find it more difficult to get a reference in the first place. For similar reasons, referees should also monitor their refereed coworkers once they are hired, thus making them more productive.

However, while individual-level surveys normally contain information about search actions taken by jobseekers, it is less common to know which search method led to the job people are holding at the time of the interview. With panel surveys - which follow the same individuals over time - it is theoretically possible to retrospectively associate to an employed person a set of search methods used when he/she was looking for a new employer (provided he/she has been interviewed at that time). Nonetheless, it is rather difficult to know exactly which method led to the observed job. As a consequence there still is limited empirical evidence to test the theoretical arguments mentioned above. Some findings exist for the United 
States, which, indeed, confirm the idea that jobs found through informal networks pay higher wages ${ }^{3}$. However, many of these papers use very selected samples (Granovetter (1974), Marmaros et al. (2002), Simon et al. (1992)) while others fail to properly control for the unobserved characteristics of individuals and their personal contacts (Corcoran et al. (1980), Datcher (1983), Staiger (1990)). This paper produces evidence using representative samples for each European country and applying fixed-effect estimation techniques.

After a description of the data in section 2, the paper is broadly organised in three parts: first (section 3), empirical evidence from the ECHP is used to document variation in wage differentials between jobs found through different channels; then (section 4), these results motivate the simple theoretical model which is finally (section 5) tested against more empirical evidence. Section 6 concludes.

\section{The Data}

\subsection{ECHP and NLSY}

The European Community Household Panel is a panel dataset of households that covers all European Countries. The main advantage of this data source is the high level of cross-country comparability. This is guaranteed by standardised sampling procedures, defined by Eurostat and implemented by each country's national statistical office. Moreover, identical questions are asked to households sampled in each country, merely translated into the local language. However, several discrepancies between countries still exist ${ }^{4}$.

The dataset is also meant to keep track of changes in the demographic composition of the population over time, by recording and including in the survey all births occurred within sampled households as well as new households created from the split of existing ones. An individual questionnaire exists for all persons living in a sampled household. Sample sizes differ from country to country, with the highest sample to population ratios for the largest and the poorest countries.

The ECHP started in 1994 and 6 waves of data have been released so far, covering the period 19941999. Not all countries entered the survey at the same time and for three of them - Germany, Lux-

\footnotetext{
${ }^{3}$ Corcoran at al. (1980), Datcher (1983), Granovetter (1974), Marmaros et al. (2002), Kugler (2003), Simon et al. (1992), Staiger (1990).

${ }^{4}$ see Peracchi (2002) for a detailed description of the ECHP.
} 
embourg and United Kingdom - the original sample has been replaced after the first three waves with harmonised versions of household panels already been produced nationally: the German Socio-Economic Panel (GSOEP), the Luxembourg's Socio-Economic Panel (PSELL) and the British Household Panel Survey (BHPS). When possible data from the existing panels have been provided for the first three years too.

The sample used in this paper includes all individuals aged 16-64 who are observed in dependent employment at least in two interviews. This excludes Sweden from the analysis because it has only entered the ECHP in 1999 and only one year of data is currently available.

Employed workers in the ECHP are asked to indicate how they have found their current job. The exact phrasing of the question reads: "By what means were you first informed about your current job?”. Six possible answers are offered:

- by applying to the employer directly (including approach by an employer);

- by inserting or answering adverts in newspapers, TV, radio;

- through employment or vocational guidance agencies;

- through family, friends or other contacts;

- started own business or joined family business;

- other.

Respondents can choose only one answer. Unfortunately, this question is not asked in the PSELL and the BHPS, therefore for these two countries only data from the ECHP original sample in the first three years (1994 to 1996) can be used.

Two important variables are problematic in the ECHP. First, firm's size was initially collected only for workers in the private sector and it has then been updated for all workers only when they changed job since the previous year. As a consequence, firm's size is missing for most public sector workers. A similar problem exists for temporary jobs. Information about the type of contract (temporary vs. permanent) was not collected in the first year and then updated in the later waves for all workers. In order to use all available information and not to reduce sample sizes, observations with missing values in both of these variables have been included in the analysis (with values equal to -1) with a specific dummy to control for them.

The upper panel of table 1 describes the time and country coverage of the data used in the paper, while summary statistics of the main variables are provided in appendix II (table A1). 
Existing estimates of the wage premium paid to jobs found through informal networks are produced mostly with US data. For the sake of comparison, US estimates are also reported here. The Panel Study of Income Dynamics (PSID) is the American data source most comparable to the ECHP, however it does not contain questions about the search methods used by employed workers to find their current jobs.

This information is readily available in the National Longitudinal Survey of Youths (NLSY), a survey of a representative cohort of children aged 14 to 21 in 1979 and interviewed 17 times since then. The cross-sectional sample is supplemented by two additional samples: one with overrepresentation of blacks, Hispanics and economically disadvantaged persons and a second one meant to be representative of the military forces. Once appropriately weighted, all individuals from the three samples have been used to produce the estimates presented here.

Starting with the 1994 survey a set of questions regarding the search methods used to find the current job(s) has been included in the NLSY79 questionnaire, resulting in 4 valid observations over time for each individual (1994, 1996, 1998, 2000). As for European countries, the American sample used in the rest of the paper consists of all individuals who are observed in dependent employment at least twice.

Two main differences make the American and European data not fully comparable. First, they are produced with very different sampling procedures: the ECHP is meant to be representative of the entire population in each EU country while the NLSY is representative only of a cohort of US-citizens. Second, the NLSY question about the search method that led to the current job is slightly different and reads as follows: "which of the methods on this card led you to your being offered your current job?". 12 possible answers are shown on the card:

- contacted employer directly/interview;

- contacted public employment agency;

- contacted private employment agency;

- contacted friends and relatives;

- contacted school/university employment center;

- sent out resumes/filled out applications;

- placed or answered adverts;

- checked union/professional register;

- other (active);

- looked at adverts; 
- attended job training programs/courses;

- other (passive).

These 12 alternative answers have been regrouped into the ECHP categories according to the following criterion:

\begin{tabular}{l:}
\multicolumn{1}{c}{ NLSY } \\
\hline $\begin{array}{l}\text { contacted employer directly/interview } \\
\text { sent out resumes/filled out applications }\end{array}$ \\
\hline placed or answered adverts \\
looked at adverts
\end{tabular}

Respondents can indicate more than one method. In the estimation, the dummy for jobs found through personal contacts is equal to one for anyone who used this method to obtain his/her current job (even when other methods have also been used). The NLSY also asks the "main" method used (and in this case respondents must give only one answer) but there is a high number of missing values in this variable and results do not change substantially when the previous definition is used.

The wage measure used in the following empirical exercises is the net hourly wage, which is directly available in the NLSY and is constructed as the net monthly wage divided by the usual number of working hours per week (multiplied by 4.3 ) in the ECHP.

\subsection{Eurostat Labour Cost Surveys}

Information about recruitment costs come from the Eurostat Labour Costs Survey, a survey of European firms carried out at regular intervals since $1975^{5}$. The sample is designed to represent all firms with 10 or more employees. Total labour costs are broken down by various categories and subcategories, and, although these change from year to year, in 1992 and 1996 the percentage of total labour costs accounted for by recruitment costs is available for several countries.

The exact definition of recruitment costs is as follows: "...the sums paid to recruitment agencies, expenditure on job advertisements in the press, travel expenses paid to candidates called for interview,

\footnotetext{
${ }^{5}$ The latest release of data contain surveys for the years 1975, 1978, 1981, 1984, 1988, 1992, 1996.
} 
installation allowances paid to newly recruited staff, etc. This does not include running administration costs (office expenses, staff wages, etc.).".

Unfortunately, for 1996 - the only year that overlaps with the time coverage of the ECHP - these figures are only available for 6 countries: Austria, Finland, France, Germany, Luxembourg, Portugal. For Belgium, Denmark, Greece and the United Kingdom data are only available for 1992, while France, Luxembourg and Portugal have reported information for both 1992 and 1996. The country and year coverage of the data used in this paper are described in the lower panel of table 1.

The data refer to the manufacturing and service sectors. No information is available for firms operating in agriculture. The data are distributed in aggregate format, broken down by industry classification (2-digit NACE) and firm size.

Table 2 shows recruitment costs as a percentage of total labour costs and per employee (in ECU) in the industry and service sectors. Austria is a clear outlier with recruitment costs 5 to 10 times higher than the other countries. Eurostat could not offer any explanations for this large discrepancy, however, in the empirical exercises performed later on in the paper, country dummies are always included in the various specifications.

Being the ECHP also produced by Eurostat, the industry classification available here can be readily merged into the microdata for each country. The Eurostat Labour Costs Survey also provides information on training costs.

\section{Jobs found through personal contacts: evidence from the ECHP}

\subsection{Who finds job through personal contacts?}

I start by documenting the characteristics of jobs found through informal contacts. To this end, standard probit regressions for having found a job through informal networks have been estimated for each country, using the 1996 wave of the ECHP 6 and data for the same year from the NLSY. The set of controls include a gender dummy, age and age squared, the number of adults in the household, two dummies for the highest level of completed education, dummies for part-time, first, temporary and public sector jobs and a set of dummies for broad occupational, firm size and industry categories.

\footnotetext{
${ }^{6}$ The 1996 wave of the ECHP is the one with the widest country coverage.
} 
Results are shown in table 3. The figures represent marginal effects. There seems to be no notable regularity across countries in terms of gender, age or income. Jobs found through informal networks appear to be generally concentrated in the private sector. This is probably due to the requirement in many countries to pass a nationwide competitive exam in order to enter the public administration.

In most countries the coefficients on the occupational and educational groups are negative and significant (the reference groups being the lowest occupations and the least educated). These results indicate an interesting cross-country regularity: jobs found through personal contacts are systematically concentrated into lower occupational groups and among less educated workers. This result conforms with findings in Staiger (1990) on the NLSY.

The use of personal contacts also appears to lead more frequently to jobs in small and medium sized firms. The distribution across industries looks more varied.

\subsection{Wage premiums to jobs found through personal contacts}

Given the above finding that jobs found through personal contacts are concentrated into lower occupational and educational groups, it is reasonable to expect lower wages paid to these jobs compared to jobs found through formal channels. This can be checked by running the following OLS wage regression for each country:

$$
\ln \left(w_{i, t}\right)=\pi P E R S O N A L_{i, t}+x_{i, t}^{\prime} \beta+\nu_{i, t}
$$

where $P E R S O N A L_{i, t}$ is a dummy equal to 1 if individual $i$ used personal contacts to find the job he/she is holding at time $t, x_{i, t}$ is a set of controls which includes a constant, experience and experience squared, tenure and tenure squared, a dummy for job-to-job movers, a dummy for first job and a set of year dummies. $\nu_{i, t}$ is a random error.

All regressions are repeated with and without job's characteristics (i.e. a dummy for part-time, a dummy for temporary and a dummy for public sector jobs), occupational (22), industry ${ }^{7}$ (18) and firm size (7) dummies. The dependent variable is the log of the net hourly wage.

The estimates of $\pi$ for each country are shown in the upper panels of figure 2 and table 4 . In figure 2 the vertical bars represent $10 \%$-level confidence intervals. In order to visually show the differences in the

\footnotetext{
${ }^{7}$ No industry dummies are available for Germany (due to a particular confidentiality agreement with Eurostat).
} 
distribution and the size of the estimates across the various specifications, in all panels of figure 2 countries are ordered according to the ranking of the OLS coefficients in the upper left quadrant.

Looking at this first set of results, some important differences across countries already emerge: statistically significant coefficients range from $-2.4 \%$ in Belgium to $-11.5 \%$ in Luxembourg. In Austria and Denmark point estimates, although not significant, are positive, while in Finland and France they are negative (still not significant). Results for the US indicate no significant wage differential.

As expected, when job's characteristics are included in the set of controls (upper right panel of figure 2), wage differences are more than halved but the ranking of countries remains unchanged. The detailed results of these regressions are reported in table A2 in appendix II.

Evidence from OLS estimates, although already suggestive of the considerable cross-country variation in wage differentials, are still far from convincing. The group of workers who have access to informal networks is probably very selected and the quality of such networks is also likely to be individual specific. This implies that OLS estimates are affected by a potentially important selection bias. As long as the unobservable characteristics that influence access to social networks and their quality are fixed over time, consistent estimates can be produced introducing individual fixed-effects $\left(\varepsilon_{i}\right)$ in equation $(1)$ :

$$
\ln \left(w_{i, t}\right)=\pi P E R S O N A L_{i, t}+x_{i, t}^{\prime} \beta+\varepsilon_{i}+\nu_{i, t}
$$

This model is identified thanks to the longitudinal dimension of the ECHP. The estimates of $\pi$ are reported in the lower panels of table 4 and figure 2. Detailed results from these regressions can be found in appendix II (table A3).

The introduction of individual fixed-effects implies that wage differentials are now identified by the same worker who is observed in different jobs obtained through different channels during the sample period $^{8}$.

Figure 2 shows that the cross-country distribution of the estimates is now very different, suggesting that individual fixed effects are indeed important and that their correlation with the use of personal contacts varies considerably across countries.

In seven out of the 15 countries the effect is significant at the $10 \%$ level: in Austria, Belgium and the Netherlands jobs obtained through informal networks respectively pay $4.2 \%, 6 \%$ and $2.9 \%$ more, while in the Greece, Italy, Portugal and the UK the effect is of opposite sign: $-2.2 \%$ in Greece and Italy, $-1.3 \%$ in

\footnotetext{
${ }^{8}$ In table A1, this is called the "identifying sample" and its size varies from $5 \%$ to $26 \%$ of the entire sample.
} 
Portugal, and $-3.5 \%$ in the UK. For all other countries estimated coefficients are not significantly different from zero. Unlike other authors (Kugler (2002), Staiger (1990)), who find a positive and significant wage premium, my estimates for the US are positive but non-significant. When job characteristics are included in the set of controls, results don't change dramatically: the impact of these variables is probably largely captured by the fixed-effects.

A even larger variation emerges from the cross-sector analysis. Industry-specific wage differentials between jobs found through informal and formal methods are produced by interacting the dummy $P E R S O N A L_{i, t}$ with a full set of sector dummies:

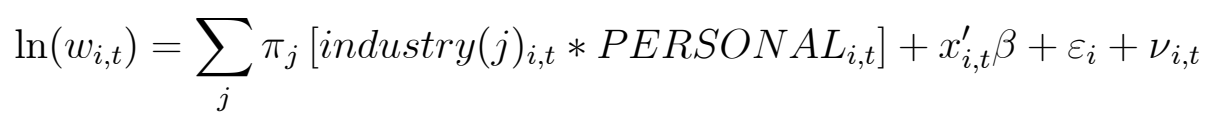

where $\operatorname{industry}(j)_{i, t}$ is a dummy equal to 1 if individual $i$ is observed working in sector $j$ at time $t$, and zero otherwise. The other symbols have the usual meaning. The sector-specific wage differentials, $\pi_{j}$ 's, are now identified by those individuals who change either sector or search method over time (or both), however the number of identifying individuals in each industry can be very small, thus reducing the precision of the estimates. For this reason, in order to achieve larger cell sizes, I have re-grouped the 18 industries available from the ECHP into 9 broader sectors. The exact definitions of the industry classification is provided in table A6, in appendix II.

Equation (3), estimated separately for each country, yields 126 (9 sectors in 14 countries) coefficients, of which only those significant at the $10 \%$ level are reported in figure 3 . As expected, because of the smaller cell sizes, these effects are larger with larger standard errors. The main message of figure 3 , however, is that wage differentials between jobs found through informal and formal methods vary considerably across sectors as well as across countries. None of the 9 broad sectors considered here shows wage differentials of the same sign in all countries. Moreover, only in 5 countries (Austria, Finland, Greece, Italy and United Kingdom) out of 15 the effects consistently point towards the existence of either a wage premium or a wage penalty to finding a job through personal contacts. In all other countries, informal search methods lead to significantly better paying jobs only in some sectors, while the opposite is true in others.

There can be at least two alternative explanations for the existence of wage differentials between jobs found through formal and informal channels. First, jobs obtained through informal networks might be 
different along some non monetary dimensions that are difficult to observe, like job security or stability, responsibility or effort, etc. In this case, wages would simply reflect compensating differentials for some permanent job specific characteristic. Alternatively, differences could be due to actual mismatching, with formal or informal channels being better or worse at matching the right worker to the right job.

These two alternative explanations have opposite empirical implications: if the wage premiums observed in the data are due to compensating differentials, then they should be permanent, i.e. they should not disappear with tenure. On the contrary, if they are due to real mismatching, then, as workers and employers move on to better job partners, these bad matches are destroyed and, consequently, wage differentials should disappear as tenure increases.

Estimates in table 5 allow to discriminate between these two hypotheses. The coefficients reported in this table come from fixed-effect wage regressions similar to (2) where the dummy for jobs found through personal contacts has been replaced by its interactions with two dummies for tenure higher and lower than 6 months, respectively:

$$
\begin{aligned}
\ln \left(w_{i, t}\right)= & \pi_{1}\left[\text { PERSONAL } L_{i, t} \cdot L O W \_T E N_{i, t}\right]+ \\
& +\pi_{2}\left[\text { PERSONAL } L_{i, t} \cdot H I G H \_T E N_{i, t}\right]+ \\
& +x_{i, t}^{\prime} \beta+\varepsilon_{i}+\nu_{i, t}
\end{aligned}
$$

If individual $i$ at time $t$ has been in his/her current job for less than 6 months, $L O W_{-} T E N_{i, t}$ takes value 1 and HIGH_TEN $N_{i, t}$ is equal to 0 , viceversa if individual $i$ at time $t$ has been in his/her current job for more than 6 months.

For these regressions the sample has been restricted to jobs created during the sample period only, to avoid stock-sampling bias that would affect all tenure effects. Hence, the figures reported in table 5 are to be interpreted as the average wage differentials in jobs with less and more than 6 months of tenure respectively ${ }^{9}$.

Apart from the anomalous case of Finland, in all other countries wage differences tend to disappear with tenure, thus suggesting that they must be due to some sort of mismatching rather than to compensating differentials. The model presented in the next section will elaborate on this assumption.

I conclude by briefly discussing the possibility that also fixed-effect estimates are biased by sample selection. Although all available observations have been included in the regressions described so far, it

\footnotetext{
${ }^{9}$ Detailed results are in table A4 the appendix.
} 
has already been mentioned that fixed-effect wage differences are identified by workers who, during the sample period, changed both job and search method (formal vs. informal) at least once. Let us call this group the "identifying sample".

Summary statistics in table A1 indicate that the size of this sub sample of workers varies between 5\% and $26 \%$ of the total. There are various potential reasons to think that the composition of the "identifying sample" differs from that of the total sample. For example, if one search channel systematically leads to well paid and stable jobs, then people who used that channel for their first job would be less likely to change employer and search method in the future.

In order to check whether this, or other sources of selection, affect the results discussed earlier, table A5 in appendix II reports results from country-by-country probit regressions for the probability of being in the "identifying sample" (marginal effects shown in the table). The estimates somehow replicate some of the results of table 3, given that in order to be in the identifying sample one must have found at least one job through personal contacts. However, there is no new systematic trend along the individual characteristics included in the set of controls, suggesting that, conditional on the observables, selection is to a large extent random.

\section{A model with endogenous recruitment effort}

The empirical results discussed in the previous section challenge a generalized belief in the literature that informal contacts contribute to improve the quality of job matches (although some working papers have already documented contrasting results for some countries. See Bentolila et al. (2003), Calvo et al. (2003)). Once comparable data for several countries are available - as in the ECHP - a large cross-country variation in the premiums paid to jobs created through informal networks emerges.

This is a new empirical result that clearly points towards the role of some underlying country-specific or labour market-specific characteristics that somehow modify the impact of informal networks on individual wages. These considerations motivate the attempt conducted in this section to construct a simple theory that explains the existence of both negative and positive premiums to jobs found through personal contacts.

Previous papers (Montgomery (1991), Mortensen et al. (1994), Simon et al. (1992)) have suggested that personal contacts transmit information between job applicants and potential employers more effec- 
tively than other channels. However, as long as personal contacts are assumed to be a better channel for the delivery of information, no explanation for the observed wide variation in wage premiums can be provided, especially for those cases in which jobs found through informal networks pay lower wages.

The most intuitive way to relax this assumption is to endogenise the amount and quality of information delivered by informal contacts relative to other recruitment channels. In other words, what matters is not the informational content of references per se, but relative to how informative other recruitment strategies are.

Moreover, firms have typically little control over the amount of information they can obtain through informal contacts and they are likely to take the value of references as exogenous. On the other hand, firms do choose their recruitment strategies as far as formal channels are concerned: set up a human resource department, decide how long and tough the interviewing process should be, buy and administer aptitudinal tests, choose the interviewers, etc. The more the firm invests in formal recruitment the more information about the worker's unobserved characteristics can be extracted.

This is the approach taken in the simple model presented here, where the key ingredient is the firm' endogenous choice of formal "recruitment effort". As the informational content of references is assumed to be exogenous (although positive and potentially very relevant), it is the effort that the firm decides to put into formal screening that determines which one of the two channels (formal vs. informal) is more informative and, consequently, which wage is higher.

Specifically, the model shows that firms invest more in formal recruitment for filling high productivity jobs and jobs that involve substantial training. Consequently, positions with these characteristics are comparatively more likely to be filled with suitable candidates through formal channels than informal ones, the first being more productive. As long as wages vary with productivity, this mechanism generates variation in the average quality of matches created through different channels as well as in wages.

Let us now move on to the equations of the model, which is a simple modification of a standard matching model à la Pissarides (2000). All equations are written in discrete time. In order to focus attention on the choice of the recruitment strategy, neither the supply side of the labour market nor the process of wage negotiation will be modelled here: firms always offer wages equal to an exogenous fraction $\beta$ of expected or actual productivity and workers always accept the offer. Moreover, the analysis is conducted in partial equilibrium, i.e. holding the total number of jobs fixed: each firm only has one 
vacancy and no new firms can enter the market ${ }^{10}$.

Productivity is match-specific and for each firm there exist two types of workers, suitable and unsuitable. The types are unknown to both the firm and the worker until production takes place. A job filled with a suitable worker produces $x=p>0$, unsuitable workers produce $x=0$. In order to start operating a job and before knowing the worker's type, a fraction $k$ of productivity $p$ must be spent on training.

Firms meet workers with per-period probability $q$. Conditional on having met a worker, he/she can arrive through the formal or the informal channel with probabilities $\delta$ and $(1-\delta)^{11}$.

Through each channel employers can meet either suitable or unsuitable candidates and, by undertaking recruitment activities, they can improve the probability of being matched to a suitable one. This is captured in the model by a "recruitment function" $\zeta\left(R_{f, i}\right)$ which represents the probability of being matched with a suitable candidate (conditional on having met one through either of the two channels) and where $R_{f}$ represents formal recruitment effort and $R_{i}$ is its analog for the informal channel.

In other words, in each period 5 events can occur for each unfilled vacancy:

\begin{tabular}{lc}
\multicolumn{1}{c}{ Event } & Probability \\
\hline $\begin{array}{l}\text { 1. the vacancy remains unfilled } \\
\text { 2. the vacancy is filled with a suitable } \\
\text { candidate through the formal channel }\end{array}$ & $\mathrm{q} \delta \zeta\left(\mathrm{R}_{\mathrm{f}}\right)$ \\
$\begin{array}{l}\text { 3. the vacancy is filled with an unsuitable } \\
\text { candidate through the formal channel }\end{array}$ & $\mathrm{q} \delta\left(1-\zeta\left(\mathrm{R}_{\mathrm{f}}\right)\right)$ \\
$\begin{array}{l}\text { 4. the vacancy is filled with a suitable } \\
\text { candidate through the informal channel }\end{array}$ & $\mathrm{q}(1-\delta) \zeta\left(\mathrm{R}_{\mathrm{i}}\right)$ \\
$\begin{array}{l}\text { 5. the vacancy is filled with an unsuitable } \\
\text { candidate through the informal channel }\end{array}$ & $\mathrm{q}(1-\delta)\left(1-\zeta\left(\mathrm{R}_{\mathrm{i}}\right)\right)$ \\
\hline
\end{tabular}

In this framework, recruitment effort - $R_{f, i}$ - can be interpreted both as extensive and intensive recruitment, i.e. employers can improve the probability of finding a suitable worker by intensifying their searching activities (e.g. by advertising more and in better selected newspapers, by organising events at professional schools and/or colleges, etc.) and/or by intensifying their screening activities (e.g. more and more accurate interviews, aptitudinal tests, etc.). The $\zeta(\cdot)$ function is a convenient modelling tool to capture the joint effect of both sets of activities.

\footnotetext{
${ }^{10}$ Most of the comparative statics effects will, however, carry through in general equilibrium as well.

${ }^{11}$ This is just a convenient solution to allow firms to hire through both channels simultaneously. Several alternative assumptions are possible about the meeting probabilities but none of the empirical implications depend crucially on these.
} 
$R_{i}$ is to be interpreted as the informational value of personal contacts: filling a vacancy with a suitable candidate through the informal channel is as likely as through formal methods with effort equal to $R_{i}$. A crucial assumption of the model will be that $R_{i}$ is exogenous to the firm, while $R_{f}$ is chosen optimally to maximise the value of an unfilled vacancy.

The properties of $\zeta(\cdot)$ are intuitive: in the absence of any screening - $\zeta(0)$ - the probability of meeting a suitable candidate is simply equal to the fraction of such workers in the pool of job applicants, as $R_{f, i} \rightarrow \infty, \zeta\left(R_{f, i}\right) \rightarrow 1$. Hence, $\zeta\left(R_{f, i}\right)$ is increasing and concave in $R_{f, i}$. Additionally, the return to $R_{f, i}$ should tend to zero when the number of suitable workers goes either to 1 or to zero: there is no advantage in screening candidates when they are all either suitable or unsuitable for the job ${ }^{12}$.

Firms optimally choose formal recruitment effort - $R_{f}$ - by trading off the benefits of a higher probability of creating a good match with the linear costs of recruitment, $c R_{f}$. Informal contacts provide some exogenous information - $R_{i}$ - about candidates, which comes at no cost to the firm but cannot be adjusted optimally. It must be noted here that also applicants contacted via informal methods typically go through a screening process, but this is usually shorter and less intense ${ }^{13}$. For simplicity, the model makes the extreme assumption that candidates met through informal contacts do not go through formal screening.

Given the above assumptions and a per-period discount rate $r$, the value of a vacancy to a representative firm is:

$$
\begin{aligned}
V= & -c R_{f}+\frac{q}{1+r}\left\{\delta \zeta\left(R_{f}\right)\left[J_{f}(p)-k p\right]+\delta\left(1-\zeta\left(R_{f}\right)\right)\left[J_{f}(0)-k p\right]+\right. \\
& \left.+(1-\delta) \zeta\left(R_{i}\right)\left[J_{i}(p)-k p\right]+(1-\delta)\left(1-\zeta\left(R_{i}\right)\right)\left[J_{i}(0)-k p\right]\right\}+ \\
& +\frac{1-q}{1+r} V
\end{aligned}
$$

where $J_{f, i}(p)$ and $J_{f, i}(0)$ are the value of a job filled with a suitable and unsuitable worker, respectively ${ }^{14}$. A job filled with a suitable candidate produces $x=p$ and is never destroyed. An initial wage -

\footnotetext{
${ }^{12}$ For example, an appropiate functional form for $\zeta(\cdot)$ could be the following:
}

$$
\zeta(R)=1-(1-n) e^{-n R}
$$

where $n$ is the fraction of suitable workers.

${ }^{13}$ This as well as other assumptions made here about the behaviour of firms will be discussed in a companion paper using establishment level data for the United Kingdom (Survey of Employers' Recruitment Practices, 1992).

${ }^{14}$ In this specification it is assumed that recruitment costs are paid ex-ante, i.e. before meeting workers. This is consistent 
$w_{f, i}$ - equal to expected productivity is paid in the first period and is later updated to a fraction of actual productivity for all the subsequent periods. A job filled with an unsuitable candidate produces $x=0$, the initial wage - $w_{f, i}$ - must be paid for one period before the worker is dismissed and the vacancy re-opened. Given the above assumptions, $J_{f, i}(p)$ and $J_{f, i}(0)$ can be written as:

$$
\begin{aligned}
J_{f, i}(p) & =p-w_{f, i}+(1-\beta) \frac{p}{r} \\
J_{f, i}(0) & =-w_{f, i}+\frac{1}{1+r} V
\end{aligned}
$$

where $w_{f, i}=\beta \zeta\left(R_{f, i}\right) p$.

Firms choose $R_{f}$ in order to maximise equation (5) according to the following first order condition:

$$
\begin{aligned}
0= & \delta \zeta^{\prime}\left(\widehat{R}_{f}\right)\left[c \widehat{R}_{f}+\frac{q}{1+r} k p+(1-\beta)(1+r+q) p\right]- \\
& -c\left[\frac{r}{q}(1+r+q)+\delta \zeta\left(\widehat{R}_{f}\right)+(1-\delta) \zeta\left(R_{i}\right)\right]
\end{aligned}
$$

The effects of the parameters on the optimal level of recruitment, $\widehat{R}_{f}$, can be easily computed from equation (8). The following paragraphs give the intuition of the comparative statics, while the detailed proofs are shown in appendix I.

The effect of productivity $(p)$ is rather intuitive: for a highly productive job forgone earnings from keeping the vacancy open are higher and, additionally, if an unsuitable worker is hired, the firm incurs in a higher loss because of the higher wage. Both effects induce more investment in recruitment ${ }^{15}$.

Higher training costs $(k)$ also lead to higher $\widehat{R}_{f}$. For the same level of productivity, higher training costs induce firms to invest more in recruitment in order not to have to train several workers before finding a suitable one.

$\widehat{R}_{f}$ also increases with the meeting probability, $q$. This is analog to the "discouraged-job" effect described in Pissarides $(2000)^{16}$ : a higher probability of finding a worker increases the value of a vacancy and firms respond by recruiting more intensively.

with empirical evidence from firms' data. However, the empirical implications of the model remain unchanged under the alternative assumption that recruitment costs are only paid if a worker is hired through the formal channel.

${ }^{15}$ Note that this results does not depend on the assumption that unsuitable workers are totally unproductive. In particular, a similar model in which unsuitable workers produce a fraction of $p$ will give the same implication.

${ }^{16}$ Chapter 5, pag. 130. 
For the same reason also a higher $\delta$, the parameter that describes the relative importance of the formal relative to the informal channel, has a positive effect on $\widehat{R}_{f}$.

Finally, investment in formal recruitment decreases with $R_{i}$, the informational value of personal contacts.

Turning now to wages, the model readily predicts that continuation wages are identical for all matches regardless of the recruitment channel used to create them. This conforms with the empirical evidence presented in the previous sections that wage differentials fade away with tenure (see table 5). Initial wages, however, differ and their ratio depends on the relative efficiency of formal vs. informal screening:

$$
\frac{w_{i}}{w_{f}}=\frac{\zeta\left(R_{i}\right)}{\zeta\left(\widehat{R}_{f}\right)}
$$

Clearly, the premium paid to jobs found through personal contacts decreases with productivity, with training costs and with the formal meeting probability. It increases with the informational value of informal networks $-R_{i}$.

\section{Testing the empirical predictions of the model}

The model presented in the previous section contains two main empirically testable implications. The first is equation (8), which suggests that investment in recruitment is positively correlated with productivity $(p)$, training costs $(k)$ and the meeting rate $(q)$, and negatively correlated with the informational value of personal contacts $\left(R_{i}\right)$. The second is equation (9), which implies that the wage premium to finding a job through personal contacts $\left(\frac{w_{i}}{w_{f}}\right)$ is correlated negatively with investment in recruitment $\left(\widehat{R}_{f}\right)$ and positively with the informational value of personal contacts $\left(R_{i}\right)$.

In this section each of these implications will be tested against the empirical evidence using industrylevel data. Moreover, a reduced form of the model in which relative wages depend negatively on productivity and training, controlling for labour market conditions, will also be tested using both industry- and individual-level data.

As discussed in section 2.2, the 1992 and 1996 Eurostat Labour Costs Surveys contain information on both recruitment and training costs at the industry level, which can be used to construct empirical counterparts of $R_{f}$ and $k$. Measures of productivity at the industry level are also readily available from 


\section{Eurostat.}

Unfortunately, $R_{i}$ cannot be easily observed and additional identification assumptions are needed. In particular, personal contacts will be assumed to be equally informative within each country, so that $R_{i}$ can be controlled for by country dummies. This restriction does not come at no cost, specifically it implies I will be able to explain the variation in wage differentials between jobs found through different channels only across sectors and within countries.

The measurement of $q$ also requires some discussion. Following the conventional view of the matching function, meeting probabilities for firms depend positively on the number of jobseekers and negatively on the number of unfilled vacancies. However, workers typically search for jobs across industries, hence a measure of labour supply (i.e. the unemployment rate) at the industry level is hard to define and construct. Variation in labour demand at the industry level (i.e. the number of vacancies) is therefore likely to capture a large fraction of the variation in meeting rates across industries.

An internationally comparable measure of labour demand can be constructed from the OECD Business Trend Survey, a quarterly survey of businesses' expectations in the manufacturing sector in selected OECD countries. Among other things, employers are asked whether they are planning to increase/decrease or maintain constant their work force in the following 3 months.

The measure of labour demand that will be used here is computed as the annual average of the difference between the fraction of respondents who expect to increase and decrease their employment. I will call this variable "employment trend". A positive number indicates that throughout the year firms have been posting new vacancies rather than closing down jobs. According to the definition of meeting probability, in markets where firms are posting more vacancies the probability of meeting a worker is lower. Although this is only an indirect and imperfect measure of labour demand, it is, to my knowledge, the only internationally comparable source of information about vacancies.

Test 1: the determinants of recruitment effort. With these data, the effects of the level of productivity and training costs on recruitment effort can be identified by estimating the following regression at the industry level:

$$
R_{c, s, t}=\alpha_{1} p_{c, s, t}+\alpha_{2} k_{c, s, t}+\alpha_{3} e m p_{c, s, t}+\eta_{c}+\nu_{t}+\varepsilon_{c, s, t}
$$

where $R_{c, s, t}, p_{c, s, t}$ and $k_{c, s, t}$ are annual recruitment costs, annual output and annual training costs per 
employee in country $c$, sector $s$ and year $t$ (all in logs of current ECU), respectively; $e m p_{c, s, t}$ is the measure of labour demand described above; $\eta_{c}$ is a country dummy and $\nu_{t}$ is a year dummy. $\varepsilon_{c, s, t}$ is the error term, clustered by country-industry cells.

Results are shown in table 6. Since employment trend is only available for the manufacturing sector, this variable is omitted in the first column, which shows the estimates for both the manufacturing and the service sectors. As predicted, firms spend more on recruitment in industries in which jobs are more productive and more training is provided. Column 2 repeats the estimation for the manufacturing sector only and results are confirmed ${ }^{17}$.

Finally, column 3 includes employment trend as a regressor and, once again, the coefficients on productivity and training costs are positive and strongly significant ${ }^{18}$. Employment trend is also found to have a significant and negative effect suggesting that firms invest less in recruitment in tighter labour markets, the "discouraged-job" effect mentioned earlier on.

Test 2: wage differentials and recruitment costs. Turning now to equation (9), the predicted negative correlation between the wage differential $\left(\frac{w_{i}}{w_{f}}\right)$ and recruitment can be tested by running a fixed-effect wage regression similar to (2), pooling all countries together and introducing an interaction term between the dummy for jobs found through personal contacts and average recruitment costs in the corresponding industry in $1996, R_{s, 96}$ :

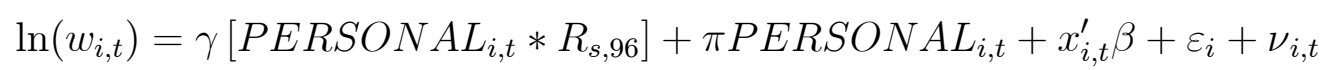

Time-variation in the interaction term will only be generated by individuals observed in jobs found via different channels. Unfortunately, only 5 countries - Austria, Finland, France, Luxembourg and Portugal provided data on recruitment in 1996.

Results are shown in the first column of table 7 and, indeed, confirm the prediction of the model. In this specification, however, the coefficients on all the controls $\left(x_{i, t}\right)$ are constrained to be the same for

\footnotetext{
${ }^{17}$ The reason why in column 2 there are more observations than coumn 1 is because, while training and recruitment data come at a very detailed industry level (NACE rev.1), productivity at such a disaggregated level is only available for the manufacturing sector. If one wants to include the service sector too, many manufactory subindustries must be reaggregated at a higher level.

${ }^{18}$ The number of observations is now much smaller because, in the process of matching data from Eurostat (recruitment, training and productivity) with data from the OECD (business trend), some sectors are lost and others have to be reaggregated to a higher level.
} 
all countries. The second column of table 7 reports results obtained from the same equation, when all the $x_{i, t}$ 's are interacted with a full set of country dummies to allow for country-specific coefficients. The estimates are virtually identical.

Test 3: the reduced form model. Equations (8) and (9) can be combined into a reduced form model, in which relative wages depend negatively on productivity and training, controlling for labour market conditions and country (or individual) fixed-effects.

This model can be tested in two alternative ways. First, industry-level data on productivity, training and employment trend can be matched into the ECHP to check whether they are correlated with the wage differentials $\left(\frac{w_{i}}{w_{f}}\right)$.

This is done in the upper panel (panel A) of table 8. In the first two columns, the basic model refers to a regression similar to equation (11), where the interaction between $P E R S O N A L_{i, t}$ and $R_{s, 96}$ is replaced with interactions terms between $P E R S O N A L_{i, t}$ and productivity, training costs an employment trend. In the fully interacted model, all controls are interacted with country dummies. Both specifications are estimated for the manufacturing and service sectors together, and for manufacturing only. In the latter case, the employment trend variable can be included.

Results are now less clear. The coefficients are always very small and never statistically significant. The point estimates seem to contradict the prediction of the model.

The lower panel (panel B) of table 8 presents an alternative test of the reduced form model. The ECHP contains information on occupation categories which can be used to test the effect of productivity: as long as jobs in higher level occupations are more productive, one would expect the premium paid to jobs found through informal networks to be lower in higher occupations. Information on training is also available in the ECHP. Employed workers are asked to indicate whether they have received any training that they are finding useful in their current job. Unfortunately, it is not possible to know whether training has been provided by the current or a previous employer. The model predicts that, in these jobs, the premium to personal contacts should be lower. Note that individual fixed effects are likely to be a good control for the informational value of references $\left(R_{i}\right)$, which can now vary at the individual level. A set of regional dummies is included to control for local labour market conditions.

Eventually, the reduced form model is tested by estimating the following fixed-effect wage regression: 


$$
\begin{aligned}
& \ln \left(w_{i, t}\right)=\sum_{j} \theta_{j}\left[\operatorname{Occup}(j)_{i, t} * \operatorname{PERSONAL_{i,t}]+}\right.
\end{aligned}
$$

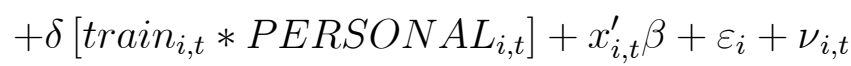

where $O \operatorname{ccup}(j)_{i, t}$ is a dummy equal to 1 if individual $i$ at time $t$ is holding a job in the $j^{\text {th }}$ occupational group, $\operatorname{train}_{i, t}$ is a dummy equal to 1 if individual $i$ indicates to have received training which is useful in carrying out the job he's holding at time $t$ and the other symbols have the usual meaning. Three standard broad occupational dummies are considered: high, intermediate and lower occupations. Estimates now confirm the predictions of the model.

Similarly to equation (11), also equation (12) can be improved by allowing all coefficients on the $x_{i, t}$ 's to vary by country. This is done in the second column of table 8 (panel B), where, once again, the estimates suggest that the wage premium paid to jobs found through informal networks is lower in higher occupations. The coefficient on the training interaction has the expected sign but it is not significant.

Additional implications: the incidence of jobs found through personal contacts The model also predicts that, in each period, a fraction $q \delta$ of jobs is created through the formal channel and $1-\zeta\left(\widehat{R}_{f}\right)$ of these are immediately destroyed. Similarly, the informal channel leads a fraction $q(1-\delta)$ of vacancies to be filled in each period, $1-\zeta\left(R_{i}\right)$ of which are destroyed. This implies that, at the end of each period, the ratio of vacancies filled through the informal channel relative to the formal one is:

$$
P=\frac{(1-\delta)}{\delta} \frac{\zeta\left(R_{i}\right)}{\zeta\left(\widehat{R}_{f}\right)}
$$

Equation (13) suggests that the probability of observing a job filled though the formal channel is lower when firms invest more in formal recruitment. This is tested in table 9 which reports results from the following probit regression on the pooled sample of individuals from all countries:

$$
\operatorname{Pr}\left(y_{i}=1\right)=\Theta\left(\gamma R_{s}+x_{i}^{\prime} \beta\right)
$$

where $y_{i}$ is equal to 1 if individual $i$ has found her current job through personal contacts and zero otherwise. As above, $R_{s}$ is the log of average recruitment costs per employee in the industry $s$ where individual $i$ is observed. $\Theta(\cdot)$ is the cumulative of the normal distribution. The estimation is run using data 
from the 1996 wave of the ECHP, which is the one that allows the widest country coverage, and excluding individuals with less than one year of tenure. The set of controls is the same as in table 3, except that here all countries have been pooled together.

The estimate of $\gamma$ is shown in the first column of table 9 and confirms the prediction that less jobs are found through personal contacts when firms invest more in recruitment activities. The second column of table 9 reports the results obtained from the same model when the coefficients of all the controls are allowed to vary by country. The point estimate is still negative but not significant.

Similarly to equation (9), the reduced form version of equation (13) can also be tested using either industry-level or individual-level regressors for productivity and training. The upper panel (panel A) of table 10 exploits the first option and contains estimates of probit regressions similar to (14) where $R_{s}$ is replaced by productivity, training and employment trend corresponding to the industry in which individual $i$ is observed. Once again, the estimation is performed with fixed (basic model) and country-specific (fully interacted model) coefficients for the controls as well as for manufacturing and industry together and for manufacturing only.

Results are mixed: in the basic model (column 1 and 2) productivity appears to have the predicted negative and significant effect on wage differentials, while the effect of training is either non significant or of the wrong sign. These findings are reversed in the fully interacted model (column 3 and 4) where productivity shows a positive effect (either significant or not) and the coefficient of training has the expected negative sign (significant in one specification).

Alternatively, a test of the reduced form of equation (13) using individual level data is shown in the lower panel (panel B) of table 10. This is done by running the following probit regression:

$$
\operatorname{Pr}\left(y_{i}=1\right)=\Theta\left(\sum_{j} \theta_{j} O \operatorname{ccup}(j)_{i}+\delta T R A I N_{i}+x_{i}^{\prime} \beta\right)
$$

where the symbols have the same meaning as in equation (12). Regional dummies are also added to the set of controls. Results are now clearly supporting the predictions of the model: there are less jobs created through the informal channel in high occupations as well as in positions that require more training. 


\section{Conclusions}

How does this paper answer the question of the title? Do friends and relatives really help in getting a good job? It depends.

The first part of the paper documents that, contrary to the common belief, informal search channels not always lead to significantly better paid jobs. Across countries and industries wage premiums and wage penalties to finding a job through personal contacts are equally frequent. Workers' and jobs' observable characteristics are controlled for in computing these wage differentials and individual fixed-effect are also introduced to account for the fact that both access to informal networks and the quality of information transmitted via personal contacts might be individual specific. Moreover, the fact that wage differentials between jobs found through formal vs. informal channels disappear with tenure suggests that they probably originate from some kind of mismatch.

The paper then moves on to presenting a simple model in which firms invest optimally in formal recruitment to improve the probability of being matched to a suitable worker. In this model, even if informal networks also provide useful information about applicants and help forming good matches, jobs created trough formal methods can on average be of better quality, if investment in formal recruitment is large enough. This happens more likely when employers are filling high productivity jobs, because the cost of hiring an unsuitable worker is higher, both in terms of forgone profits and higher wages paid out. Firms also invest more in recruitment when training costs are high, because a new worker will have to be trained again if the hire turns out to be unfit for the job.

In the last part of the paper, industry level data for several European countries are used to show that, indeed, firms spend more on recruitment when both productivity and training costs are higher. An interesting "discouraged-job" effect is also found: expenditure on recruitment activities is lower in tighter labour markets. Finally, the wage premium to finding a job through personal contacts is shown to be negatively correlated with expenditure in recruitment activities and, consequently, also lower in high productivity occupations and in jobs that require training.

Analysing the role of informal networks in the labour market is interesting in itself, given the extensive use that both firms and workers make of them. It also allows to shed light on some sources of wage dispersion that have not yet been fully explored. Moreover, this paper takes the rather unconventional approach to look at variation in formal recruitment practices as a source of wage differentials between 
jobs found through different search channels. In doing this it touches a field that has received surprisingly little attention by economists: while the search behavior of jobseekers has been extensively studied, very little is known about how firms look for workers. This paper is an example of how a deeper understanding of firms' recruitment policies can help answering questions that are still unresolved.

This work could be extended in several directions. As workers are supposed to react to firms recruitment policies, the supply side of the labour market should also be modelled. Intuitively, if workers are unaware of their type, i.e. they don't know ex-ante if they are properly qualified for the job, the main results shown here should not change. However, if workers have some information about their type, some form of self selection could arise, with workers being more likely to apply to vacancies that better fit their characteristics when the screening process is stricter. In such framework, firms' benefits of investing in recruitment should increase: not only does a stricter recruitment policy allow them to select good candidates (just like in the model presented here), but it also induces more self selection of workers in the first place, thus increasing the average quality of the pool of candidates.

More research is also needed to understand how employers choose their recruitment strategies and how these affect overall labour market performance. To do this more and better firm level data are necessary. A companion paper, based on an original dataset of filled vacancies in more than 5,000 British establishments, will look at the micro and macro determinants of both the intensity and the types of recruitment practices used by employers. 
Tables and Figures 
Table 1: Sample composition by country and year

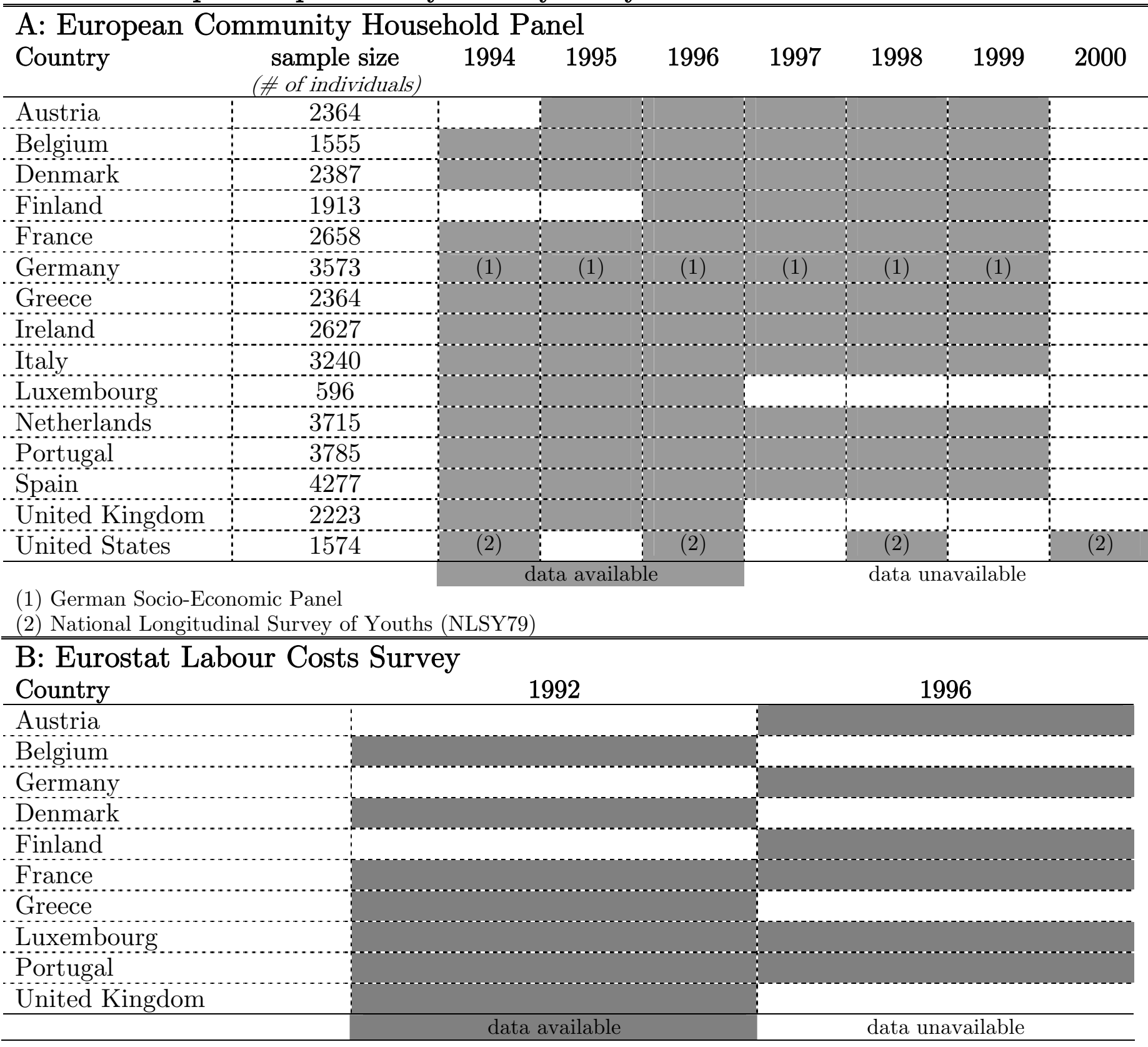


Table 2. Recruitment costs in European countries

\begin{tabular}{|c|c|c|c|c|c|}
\hline \multirow{2}{*}{ Country } & \multirow{2}{*}{ Sector } & \multicolumn{2}{|c|}{$\begin{array}{l}\% \text { of total annual labour } \\
\text { costs }\end{array}$} & \multicolumn{2}{|c|}{$\begin{array}{l}\text { spending per employee in } \\
\text { current ECU }\end{array}$} \\
\hline & & 1992 & 1996 & 1992 & 1996 \\
\hline \multirow[t]{2}{*}{ Austria } & industry & - & 0.50 & - & 204.45 \\
\hline & services & - & 1.05 & - & 471.66 \\
\hline \multirow[t]{2}{*}{ Belgium } & industry & 0.07 & - & 22.60 & - \\
\hline & services & 0.24 & - & 78.85 & - \\
\hline \multirow[t]{2}{*}{ Germany } & industry & - & 0.06 & - & 24.99 \\
\hline & services & - & 0.13 & - & 45.66 \\
\hline \multirow[t]{2}{*}{ Denmark } & industry & 0.08 & - & 24.83 & - \\
\hline & services & 0.11 & - & 32.39 & - \\
\hline \multirow[t]{2}{*}{ Finland } & industry & - & 0.11 & - & 35.72 \\
\hline & services & - & 0.17 & - & 48.88 \\
\hline \multirow[t]{2}{*}{ France } & industry & 0.09 & 0.05 & 27.52 & 18.20 \\
\hline & services & 0.14 & 0.06 & 42.62 & 20.36 \\
\hline \multirow[t]{2}{*}{ Greece } & industry & 0.01 & - & 1.32 & - \\
\hline & services & 0.01 & - & 1.27 & - \\
\hline \multirow[t]{2}{*}{ Luxembourg } & industry & 0.02 & 0.04 & 5.74 & 13.25 \\
\hline & services & 0.07 & 0.21 & 22.85 & 77.93 \\
\hline \multirow[t]{2}{*}{ Portugal } & industry & 0.03 & 0.02 & 2.96 & 2.14 \\
\hline & services & 0.06 & 0.08 & 8.24 & 11.19 \\
\hline \multirow[t]{2}{*}{ United Kingdom } & industry & 0.30 & - & 74.81 & - \\
\hline & services & 0.42 & - & 81.62 & - \\
\hline
\end{tabular}




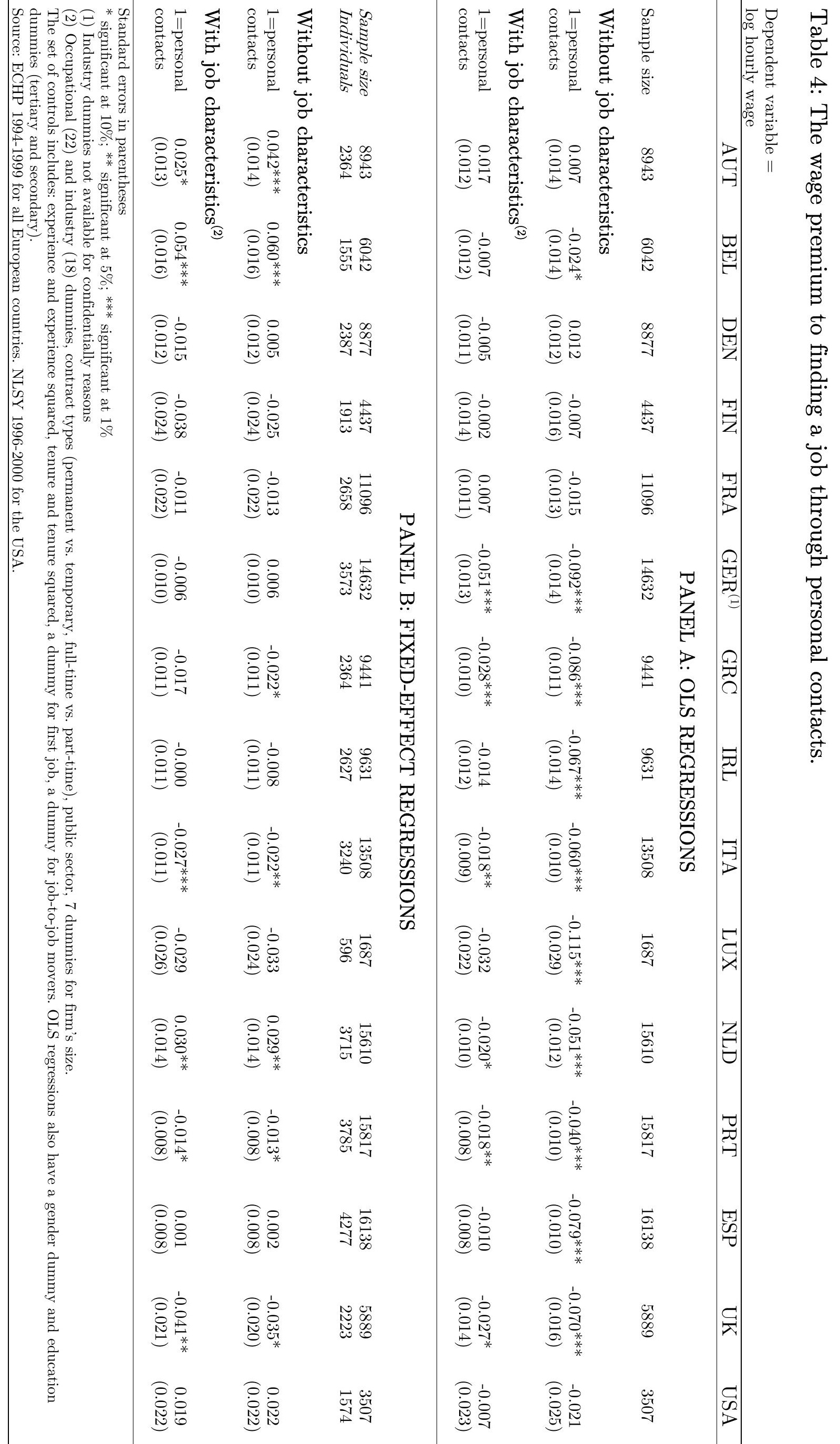




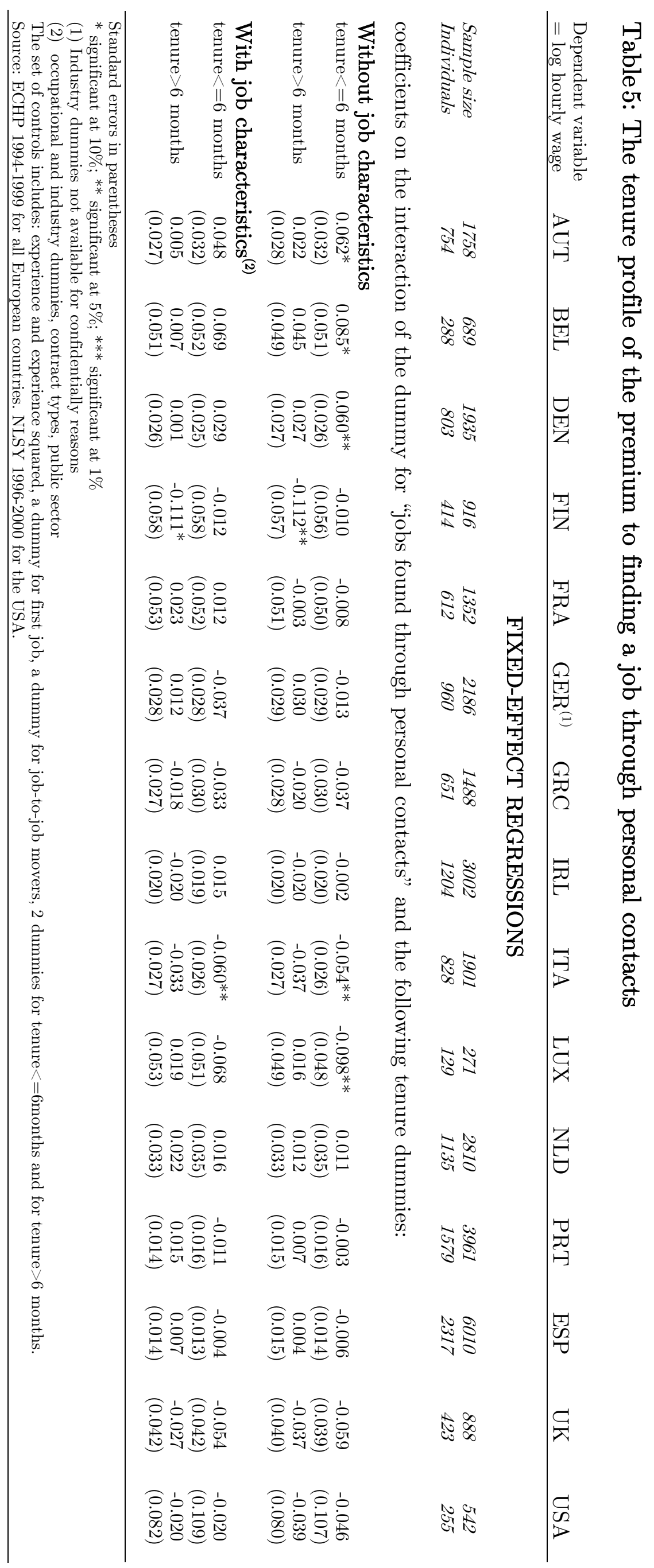




\section{Table 6: The determinants of recruitment costs}

\begin{tabular}{|c|c|c|c|c|}
\hline $\begin{array}{l}\text { Dependent variable: } \\
\text { (log) recruitment costs } \\
\text { per employee }\end{array}$ & $\begin{array}{l}\text { industry and services } \\
{[1]}\end{array}$ & $\begin{array}{c}\text { manufacturing only } \\
{[2]}\end{array}$ & $\begin{array}{c}\text { manufacturing only } \\
{[3]}\end{array}$ & $\begin{array}{l}\text { predicted } \\
\text { sign }\end{array}$ \\
\hline$(\log )$ productivity $^{(1)}$ & $\begin{array}{c}0.432^{* * *} \\
(0.099)\end{array}$ & $\begin{array}{c}0.365^{* *} \\
(0.173)\end{array}$ & $\begin{array}{c}0.371^{* *} \\
(0.165)\end{array}$ & $(+)$ \\
\hline $\begin{array}{l}\text { (log) training costs per } \\
\text { employee }\end{array}$ & $\begin{array}{c}0.482^{* * *} \\
(0.112)\end{array}$ & $\begin{array}{c}0.372^{* * *} \\
(0.061)\end{array}$ & $\begin{array}{c}0.629^{* * *} \\
(0.143)\end{array}$ & $(+)$ \\
\hline employment trend $^{(2)}$ & & & $\begin{array}{c}-0.015^{* *} \\
(0.007)\end{array}$ & $(-)$ \\
\hline Country dummies & yes & yes & yes & \\
\hline Year dummies & yes & yes & yes & \\
\hline Observations & 175 & 474 & 114 & \\
\hline R-squared & 0.81 & 0.41 & 0.88 & \\
\hline
\end{tabular}

(1) productivity is measured as output per employee (in ECU at current prices) - annual values. Source: Eurostat.

(2) difference between \% of firms expecting to increase and decrease employment in the following 3 months. Annual averages. See text for details. Source: OECD.

Countries included: Austria, Germany, Denmark, Finland, France, Greece, Luxembourg, Portugal, United Kingdom

Robust standard errors in parentheses

* significant at $10 \% ; * *$ significant at $5 \% ; * * *$ significant at $1 \%$

\section{Table 7: Wage differentials and recruitment costs}

Dependent variable:

(log) hourly wage

...interaction with [ $1=$ personal contacts]

$(\log )$ recruitment costs per employee

$-0.009^{*}$

$(0.005)$

19474

5477

0.20
Fully interacted model ${ }^{(2)}$

[2]

$-0.008^{*}$

$(0.005)$

19474

5477

0.21

R-squared

(1) Estimates come from fixed-effect (log) wage regressions on all individuals in all countries. The reported coefficients are the estimates for the interaction terms between the dummy for jobs found through personal contacts and average recruitment costs observed in the industry in which the single individual is currently working (in 1996). The set of controls includes experience and experience squared, tenure and tenure squared, a dummy for job-to-job movers, a dummy for first job, 18 industry dummies, year dummies and individual fixed effects. Wages are PPP-adjusted.

(2) As in model [1] with all controls interacted with country dummies.

Countries included: Austria, Finland, France, Luxembourg and Portugal

Robust standard errors in parentheses

* significant at $10 \% ; * *$ significant at $5 \%$; *** significant at $1 \%$ 
Table 8: Reduced form model for the wage differentials

Panel A: industry-level regressors

\begin{tabular}{|c|c|c|c|c|c|}
\hline \multirow[b]{2}{*}{$\begin{array}{l}\text { Dependent variable: } \\
\text { (log) hourly wage }\end{array}$} & \multicolumn{2}{|c|}{$\begin{array}{c}\text { Basic model } \\
{[1]}\end{array}$} & \multicolumn{2}{|c|}{$\begin{array}{l}\text { Fully interacted model }{ }^{(2)} \\
{[2]}\end{array}$} & \multirow[b]{2}{*}{$\begin{array}{c}\text { predicted } \\
\text { sign } \\
\end{array}$} \\
\hline & $\begin{array}{c}\text { industry and } \\
\text { services }\end{array}$ & $\begin{array}{l}\text { manufacturing } \\
\text { only }\end{array}$ & $\begin{array}{c}\text { industry and } \\
\text { services }\end{array}$ & $\begin{array}{l}\text { manufacturing } \\
\text { only }\end{array}$ & \\
\hline \multicolumn{3}{|c|}{...interactions with [1=personal contacts] } & & & \\
\hline$(\log )$ productivity $^{(3)}$ & $\begin{array}{c}0.003 \\
(0.009)\end{array}$ & $\begin{array}{c}0.007 \\
(0.020)\end{array}$ & $\begin{array}{c}0.003 \\
(0.009)\end{array}$ & $\begin{array}{c}0.010 \\
(0.020)\end{array}$ & $(-)$ \\
\hline $\begin{array}{l}\text { (log) training costs per } \\
\text { employee }\end{array}$ & $\begin{array}{l}-0.001 \\
(0.004)\end{array}$ & $\begin{array}{c}0.009 \\
(0.007)\end{array}$ & $\begin{array}{c}0.002 \\
(0.003)\end{array}$ & $\begin{array}{c}0.002 \\
(0.008)\end{array}$ & $(-)$ \\
\hline employment trend ${ }^{(4)}$ & & $\begin{array}{c}0.014 \\
(0.017)\end{array}$ & & $\begin{array}{c}0.011 \\
(0.016)\end{array}$ & $(+)$ \\
\hline Observations & 55941 & 13824 & 55941 & 13824 & \\
\hline Individuals & 15169 & 3885 & 15169 & 3885 & \\
\hline R-squared & 0.21 & 0.23 & 0.23 & 0.26 & \\
\hline
\end{tabular}

(1) Estimates come from fixed-effect (log) wage regressions on all individuals in all countries. The reported coefficients are the estimates for the interaction terms between the dummy for jobs found through personal contacts and the variable of interest (productivity, training costs, business trend in 1996) associated to the industry in which each individual is currently working. The set of controls includes experience and experience squared, tenure and tenure squared, a dummy for job-to-job movers, a dummy for first job, a dummy for part-time jobs, a dummy for jobs in the public sector, 22 occupational dummies, 18 industry dummies, year dummies and a constant. Wages are PPP-adjusted.

(2) As in model [1] with all controls interacted with country dummies

(3) productivity is measured as output per employee (in ECU at current prices) - annual values. Source: Eurostat.

(4) difference between \% of firms expecting to increase and decrease employment in the following 3 months. Annual averages. See text for details. Source: OECD.

Countries included: Austria, Belgium, Denmark, Finland, France, Greece, Italy, Luxembourg, Portugal, Spain.

Panel B: individual-level regressors

\begin{tabular}{|c|c|c|c|}
\hline & $\begin{array}{c}\text { Basic model }^{(1)} \\
{[1]}\end{array}$ & $\begin{array}{c}\text { Fully interacted model }{ }^{(2)} \\
{[2]}\end{array}$ & $\begin{array}{l}\text { predicted } \\
\text { sign }\end{array}$ \\
\hline \multicolumn{4}{|c|}{...interactions with $[1=$ personal contacts $]$} \\
\hline higher occupations & $\begin{array}{c}-0.023^{* * *} \\
(0.008)\end{array}$ & $\begin{array}{c}-0.022^{* * *} \\
(0.008)\end{array}$ & $(-)$ \\
\hline intermediate occupations & $\begin{array}{l}-0.010 \\
(0.006)\end{array}$ & $\begin{array}{l}-0.003 \\
(0.006)\end{array}$ & $(-)$ \\
\hline training & $\begin{array}{c}-0.012^{* * *} \\
(0.004)\end{array}$ & $\begin{array}{l}-0.004 \\
(0.004)\end{array}$ & $(-)$ \\
\hline $\begin{array}{l}\text { Observations } \\
\text { Number of id } \\
\text { R-squared }\end{array}$ & $\begin{array}{c}117147 \\
30511 \\
0.19\end{array}$ & $\begin{array}{c}117147 \\
30511 \\
0.21\end{array}$ & \\
\hline
\end{tabular}

(1) The set of controls includes experience and experience squared, tenure and tenure squared, a dummy for job-to-job movers, a dummy for first job, a dummy for part-time jobs, a dummy for jobs in the public sector, 22 occupational dummies, 18 industry dummies (9 in model [2]), regional and year dummies and individual fixed-effects. Wages are PPP-adjusted.

(2) As in model [1] with all controls interacted with country dummies.

Occupational groups

higher $=$ legislators, senior officials and managers, professionals, technicians and associate professionals.

intermediate $=$ clerks, service workers and shop and market sales workers, skilled agriculture and fishery workers.

lower (reference group) $=$ craft and related trades workers, plant and machine operators and assemblers, other elementary occupations.

Standard errors in parentheses

* significant at $10 \% ; * *$ significant at $5 \%$; *** significant at $1 \%$

All countries included. 


\section{Table 9: Incidence of jobs found through informal networks and recruitment costs}

Dependent variable

$=1$ if job found through personal contacts

(0 otherwise)

(log) recruitment costs per employee

\begin{tabular}{cc|c} 
basic model & $\begin{array}{c}\text { fully interacted } \\
\text { model }^{(1)}\end{array}$ & $\begin{array}{c}\text { predicted } \\
\text { sign }\end{array}$ \\
\hline \begin{tabular}{cc|} 
s.032*** \\
$(0.012)$
\end{tabular} & -0.002 & $(-)$ \\
yes & $(0.055)$ & \\
3734 & yes & \\
-2264.86 & 3695 & \\
& -2181.55 & \\
\hline
\end{tabular}

Country dummies

Observations

Log Likelihood

(1) In the fully interacted model all controls are interacted with country dummies.

Both specifications include a set of controls with the following variables: a gender dummy, age, age squared, \# of adults in the household, (log) household income, a dummy for first job, a dummy for temporary jobs, a dummy for part-time jobs, a dummy for public sector jobs, 22 occupational dummies and 18 industry dummies.

Robust standard errors (clustered by country and industry) in parentheses

* significant at $10 \%$; $* *$ significant at $5 \%$; ** significant at $1 \%$

Countries included: Austria, Finland, France, Luxembourg, Portugal. 


\section{Table 10: Reduced form for the incidence of jobs found through personal contacts}

\section{Panel A: industry-level regressors}

Dependent variable

$=1$ if job found through personal contacts (0 otherwise)

$(\log )$ productivity $^{(2)}$

\begin{tabular}{|c|c|c|c|c|}
\hline \multicolumn{2}{|c|}{ Basic model } & \multicolumn{2}{|c|}{ Fully interacted model ${ }^{(1)}$} & \multirow[b]{2}{*}{$\begin{array}{c}\text { predicted } \\
\text { sign }\end{array}$} \\
\hline $\begin{array}{l}\text { industry and } \\
\text { services }\end{array}$ & $\begin{array}{c}\text { manufacturing } \\
\text { only }\end{array}$ & $\begin{array}{l}\text { industry and } \\
\text { services }\end{array}$ & $\begin{array}{c}\text { manufacturing } \\
\text { only }\end{array}$ & \\
\hline $\begin{array}{c}-0.048^{* * *} \\
(0.018)\end{array}$ & $\begin{array}{c}-0.042^{* *} \\
(0.019)\end{array}$ & $\begin{array}{c}0.037 \\
(0.029)\end{array}$ & $\begin{array}{c}1.086^{* * *} \\
(0.112)\end{array}$ & $(-)$ \\
\hline \multirow[t]{2}{*}{$\begin{array}{c}0.035^{* * *} \\
(0.012)\end{array}$} & $\begin{array}{c}0.017 \\
(0.024)\end{array}$ & $\begin{array}{l}-0.013 \\
(0.061)\end{array}$ & $\begin{array}{c}-0.327^{*} \\
(0.188)\end{array}$ & $(-)$ \\
\hline & $\begin{array}{c}-0.001 \\
(0.001)\end{array}$ & & $\begin{array}{l}-0.002^{*} \\
(0.001)\end{array}$ & \\
\hline yes & yes & yes & yes & \\
\hline $\begin{array}{c}9605 \\
-5879.53\end{array}$ & $\begin{array}{c}2611 \\
-1534.18\end{array}$ & $\begin{array}{c}9537 \\
-5661.29\end{array}$ & $\begin{array}{c}2521 \\
-1384.68\end{array}$ & \\
\hline all EU & $\begin{array}{c}\text { A-B-D } \\
\text {-FI-GR-I-L-P-ES }\end{array}$ & all EU & $\begin{array}{c}\text { A-B-D-FI-GR-I-L- } \\
\text { P-ES }\end{array}$ & \\
\hline
\end{tabular}

(log) training costs per employee

employment trend ${ }^{(3)}$

Country dummies

Observations

Log Likelihood

Countries included

(1) In the fully interacted model all controls are interacted with country dummies.

(2) productivity is measured as output per employee (in ECU at current prices) - annual values. Source: Eurostat.

(3) difference between $\%$ of firms expecting to increase and decrease employment in the following 3 months. Annual averages. See text for details. Source: OECD.

The set of controls includes: a gender dummy, age, age squared, \# of adults in the household, (log) household income, a dummy for first job, a dummy for temporary jobs, a dummy for part-time jobs, a dummy for public sector jobs, 22 occupational dummies, 18 industry dummies and regional dummies.

Country abbreviations:

$\mathrm{A}=$ Austria; $\mathrm{B}=$ Belgium; $\mathrm{D}=$ Germany; $\mathrm{FI}=$ Finland; $\mathrm{GR}=$ Greece; I=Italy; L=Luxembourg; $\mathrm{P}=$ Portugal; ES=Spain

Panel B: individual-level regressors

\begin{tabular}{|c|c|c|c|}
\hline & Basic model & Fully interacted model ${ }^{(1)}$ & $\begin{array}{l}\text { predicted } \\
\text { sign }\end{array}$ \\
\hline $1=$ higher occupations & $\begin{array}{c}-0.053^{* * *} \\
(0.016)\end{array}$ & $\begin{array}{c}-0.052^{* * *} \\
(0.015)\end{array}$ & $(-)$ \\
\hline $1=$ intermediate occupations & $\begin{array}{l}-0.021 \\
(0.020)\end{array}$ & $\begin{array}{l}-0.022 \\
(0.019)\end{array}$ & $(-)$ \\
\hline $1=$ received training & $\begin{array}{c}-0.060^{* * *} \\
(0.009)\end{array}$ & $\begin{array}{c}-0.082^{* * * *} \\
(0.025)\end{array}$ & $(-)$ \\
\hline $\begin{array}{l}\text { Observations } \\
\text { Log Likelihood }\end{array}$ & $\begin{array}{c}19385 \\
-10909.20\end{array}$ & $\begin{array}{c}19373 \\
-10619.81\end{array}$ & \\
\hline
\end{tabular}

(1) In the fully interacted model all controls are interacted with country dummies.

The set of controls includes: a gender dummy, age, age squared, \# of adults in the household, (log) household income, a dummy for first job, a dummy for temporary jobs, a dummy for part-time jobs, a dummy for public sector jobs, 22 occupational dummies, 18 industry dummies and regional dummies.

Occupational groups:

higher $=$ legislators, senior officials and managers, professionals, technicians and associate professionals.

intermediate $=$ clerks, service workers and shop and market sales workers, skilled agriculture and fishery workers.

lower (reference group) $=$ craft and related trades workers, plant and machine operators and assemblers, other elementary occupations.

Robust standard errors in parentheses

* significant at $10 \%$;* significant at $5 \%$;** significant at $1 \%$

All countries included. 

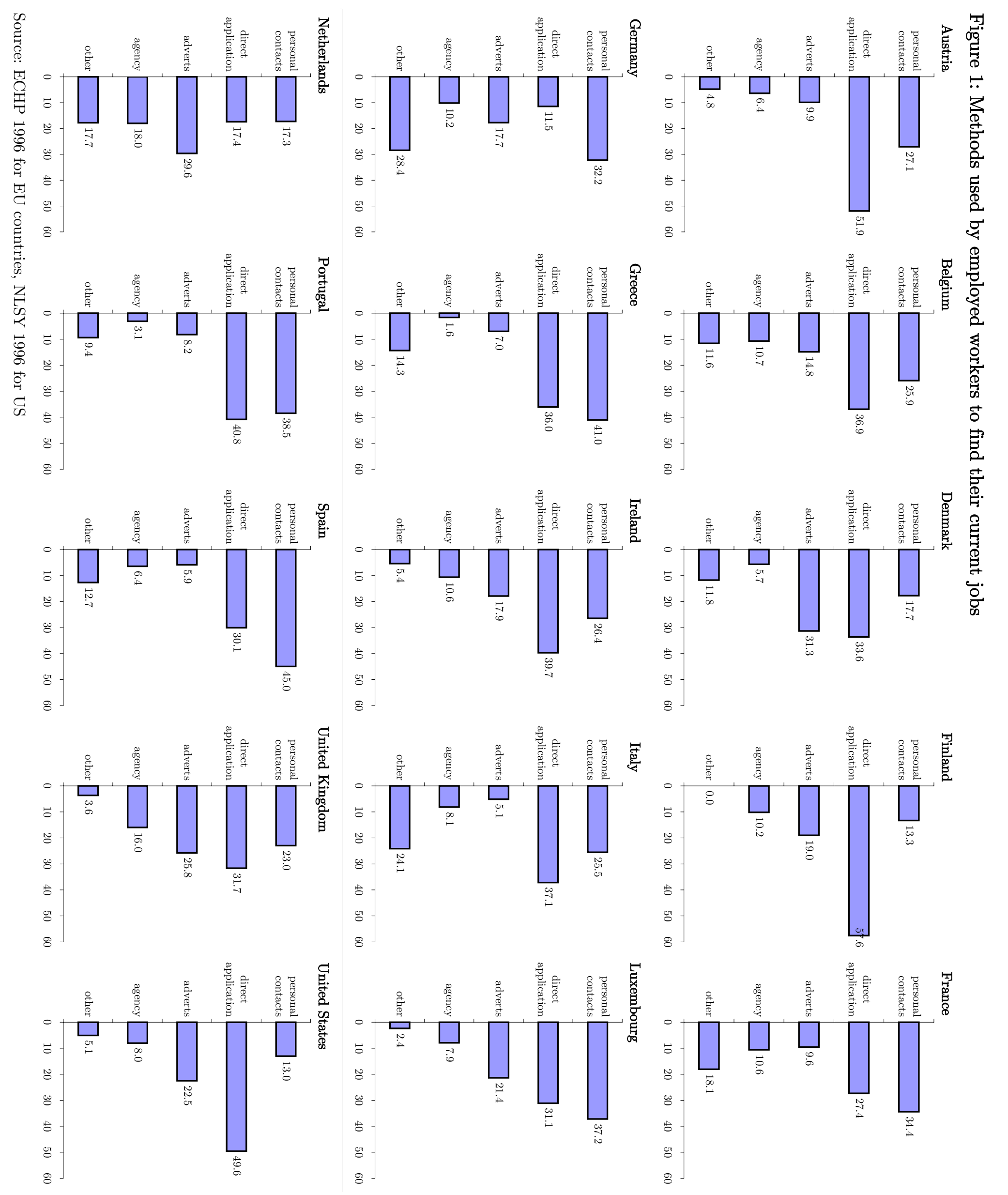
Figure 2: Wage differentials between jobs found through informal vs. formal methods
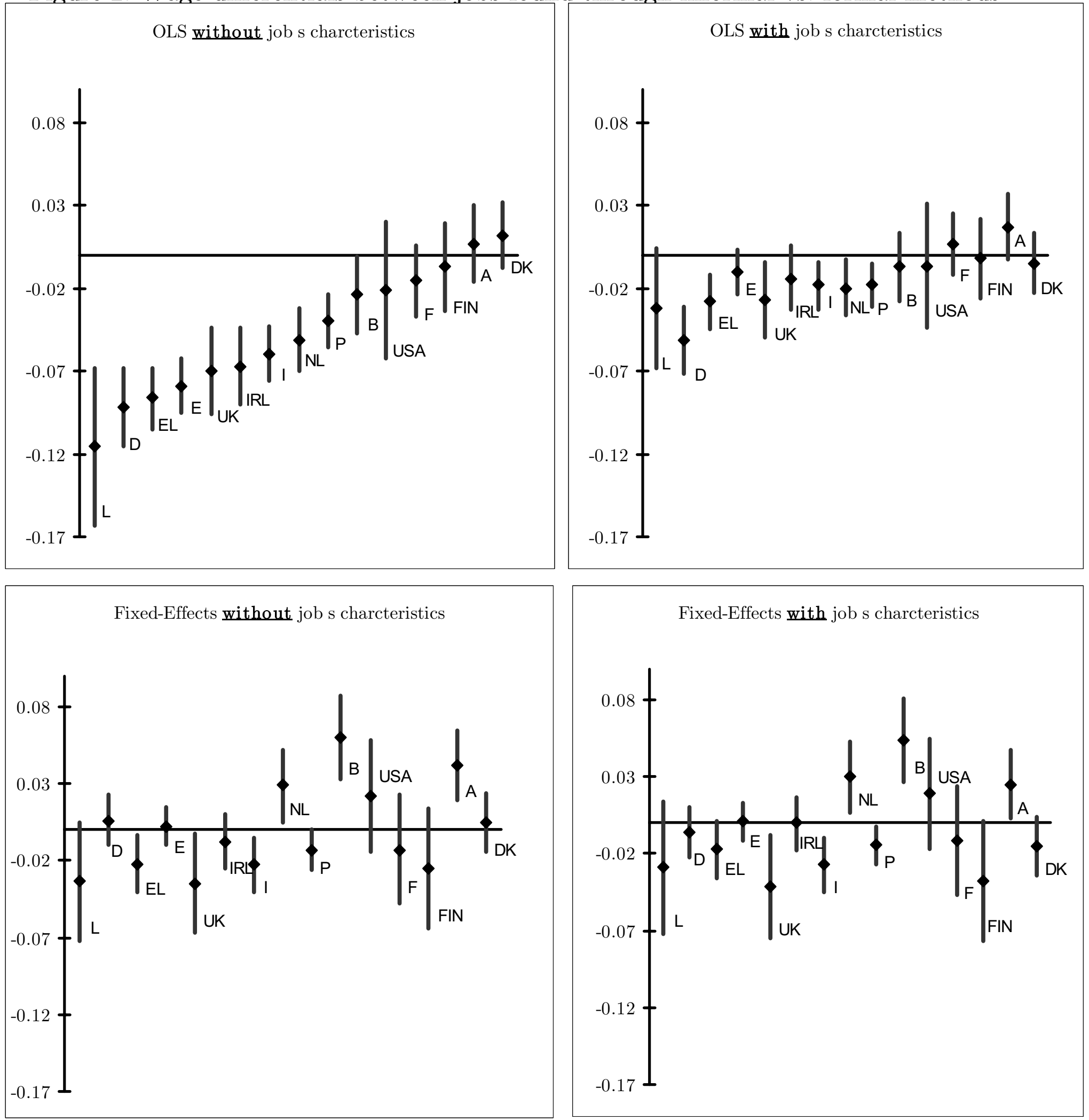

Note: The dots represent point estimates and the bars $90 \%$ confidence intervals.

Country abbreviation: $\mathrm{A}=$ Austria, $\mathrm{B}=$ Belgium, DK=Denmark, FIN=Finland, F=France, $\mathrm{D}=\mathrm{Germany}, \mathrm{EL}=\mathrm{Greece}$,

$\mathrm{IRL}=$ Ireland, I=Italy, L=Luxembourg, NL=Netherlands, $\mathrm{P}=$ Portugal, E=Spain, UK=United Kingdom, USA=United States 


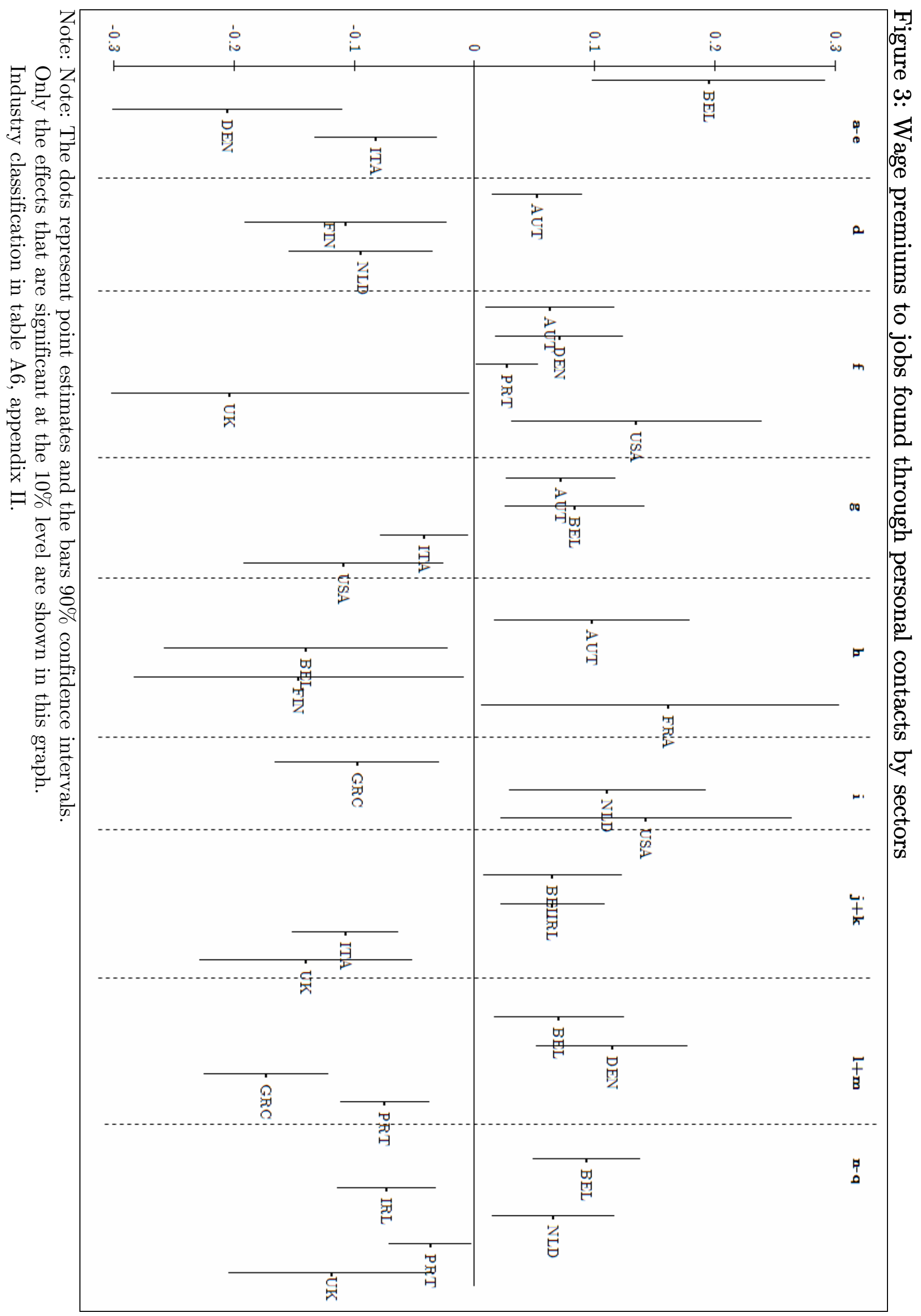




\section{Appendix I: Comparative Statics}

This section provides detailed proofs of the comparative statics effects described in the main text in section 4.

Proposition $1 \frac{d \widehat{R}_{f}}{d p}>0$

Proof. The first partial differential of equation (8) with respect to $\widehat{R}_{f}$ and $p$ yields:

$$
\begin{aligned}
0 & =\zeta^{\prime \prime}\left(\widehat{R}_{f}\right)\left[c \widehat{R}_{f}+\frac{q}{1+r} k p+(1-\beta)(1+r+q) p\right] d \widehat{R}_{f}+ \\
& +\zeta^{\prime}\left(\widehat{R}_{f}\right)\left[\frac{q}{1+r} k+(1-\beta)(1+r+q)\right] d p
\end{aligned}
$$

which, given the properties of $\zeta(\cdot)$, proves the proposition.

Proposition $2 \frac{d \widehat{R}_{f}}{d k}>0$

Proof. The first partial differential of equation (8) with respect to $R_{f}$ and $k$ yields:

$$
0=\zeta^{\prime \prime}\left(\widehat{R}_{f}\right)\left[c \widehat{R}_{f}+\frac{q}{1+r} k p+(1-\beta)(1+r+q) p\right] d \widehat{R}_{f}+\left[\zeta^{\prime}\left(\widehat{R}_{f}\right) \frac{q}{1+r} p\right] d k
$$

which, given the properties of $\zeta(\cdot)$, proves the proposition.

Proposition $3 \frac{d \widehat{R}_{f}}{d q}>0$

Proof. The first partial differential of equation (8) with respect to $R_{f}$ and $q_{f}$ yields:

$$
\begin{aligned}
0 & =\delta \zeta^{\prime \prime}\left(\widehat{R}_{f}\right)\left[c \widehat{R}_{f}+\frac{q}{1+r} k p+(1-\beta)(1+r+q) p\right] d \widehat{R}_{f}+ \\
& +\left\{\frac{\delta}{1+r} \zeta^{\prime}\left(\widehat{R}_{f}\right) k p+(1-\beta) p+\frac{r c}{q^{2}}(1+r)\right\} d q
\end{aligned}
$$

which, given the properties of $\zeta(\cdot)$, proves the proposition.

Proposition $4 \frac{d \widehat{R}_{f}}{d R_{i}}<0$

Proof. The first partial differential of equation (8) with respect to $\widehat{R}_{f}$ and $R_{i}$ yields:

$$
0=\zeta^{\prime \prime}\left(\widehat{R}_{f}\right)\left[c \widehat{R}_{f}+\frac{q}{1+r} k p+(1-\beta)(1+r+q) p\right] d \widehat{R}_{f}-\left[\frac{1-\delta}{\delta} c \zeta^{\prime}\left(R_{i}\right)\right] d R_{i}
$$

which, given the properties of $\zeta(\cdot)$, proves the proposition. 
Proposition $5 \frac{d \widehat{R}_{f}}{d \delta}>0$

Proof. The first partial differential of equation (8) with respect to $\widehat{R}_{f}$ and $R_{i}$ yields:

$$
0=\zeta^{\prime \prime}\left(\widehat{R}_{f}\right)\left[c \widehat{R}_{f}+\frac{q}{1+r} k p+(1-\beta)(1+r+q) p\right] d \widehat{R}_{f}+\left[\frac{c r}{q}(1+r+q)+(1-\delta) \zeta\left(R_{i}\right)\right] d \delta
$$

which, given the properties of $\zeta(\cdot)$, proves the proposition. 
Appendix II: Detailed tables 


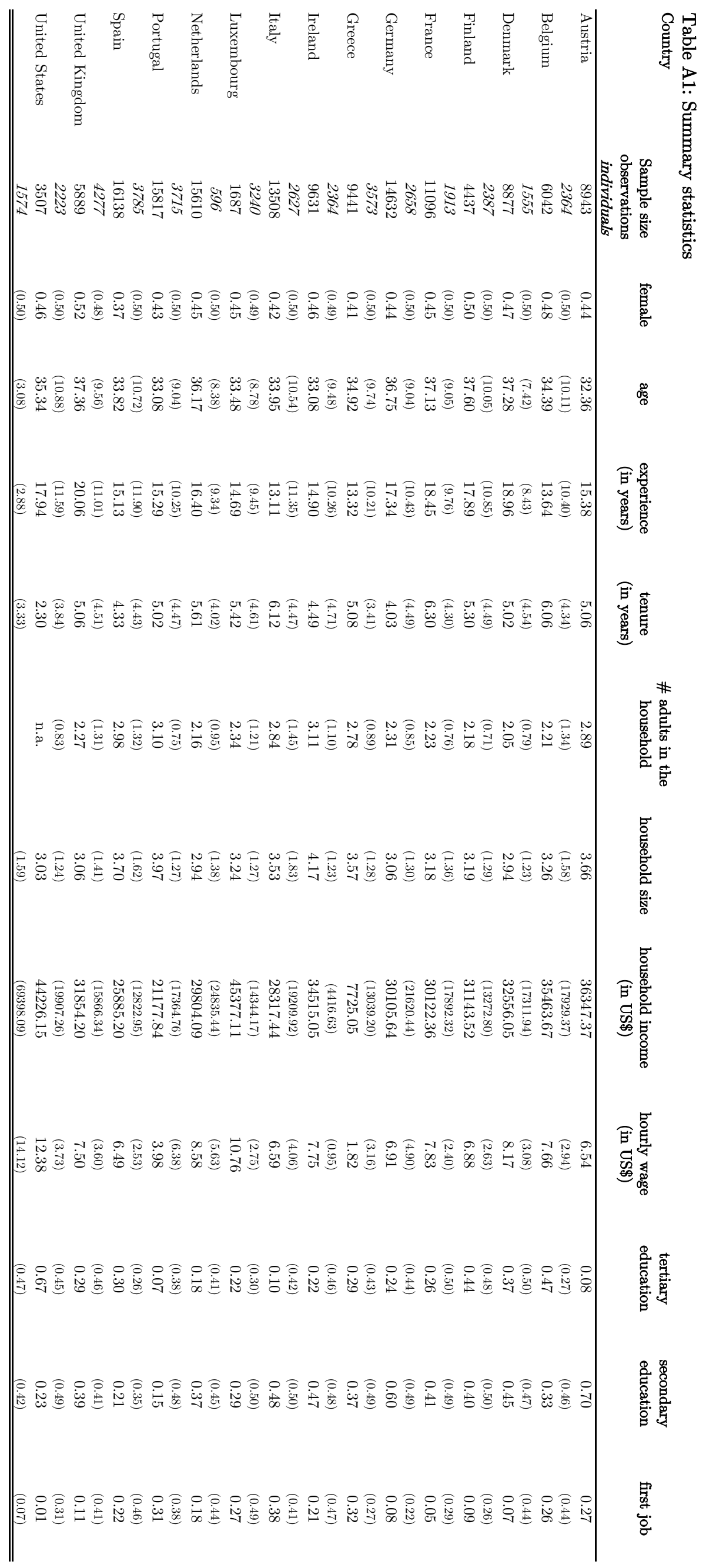




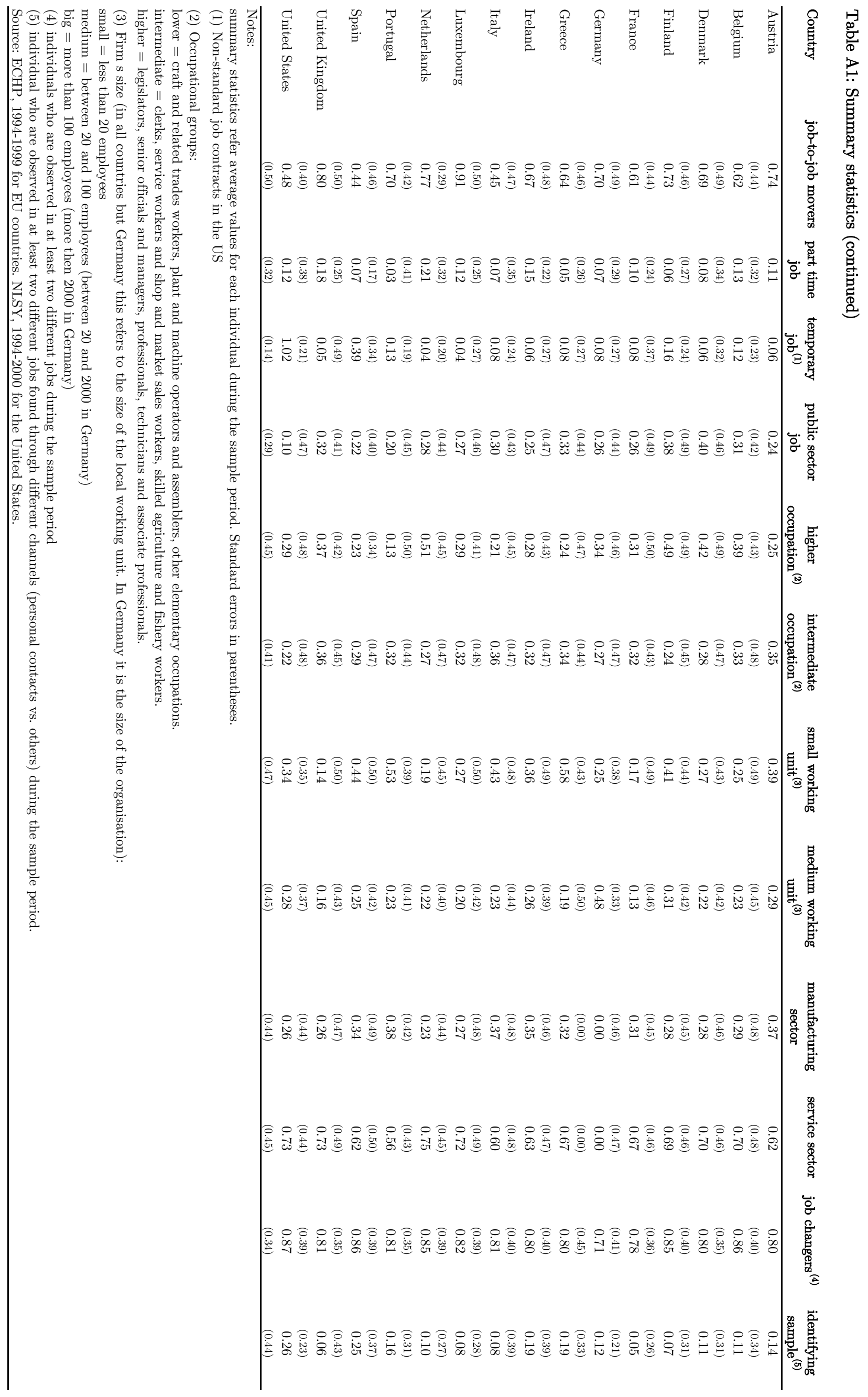




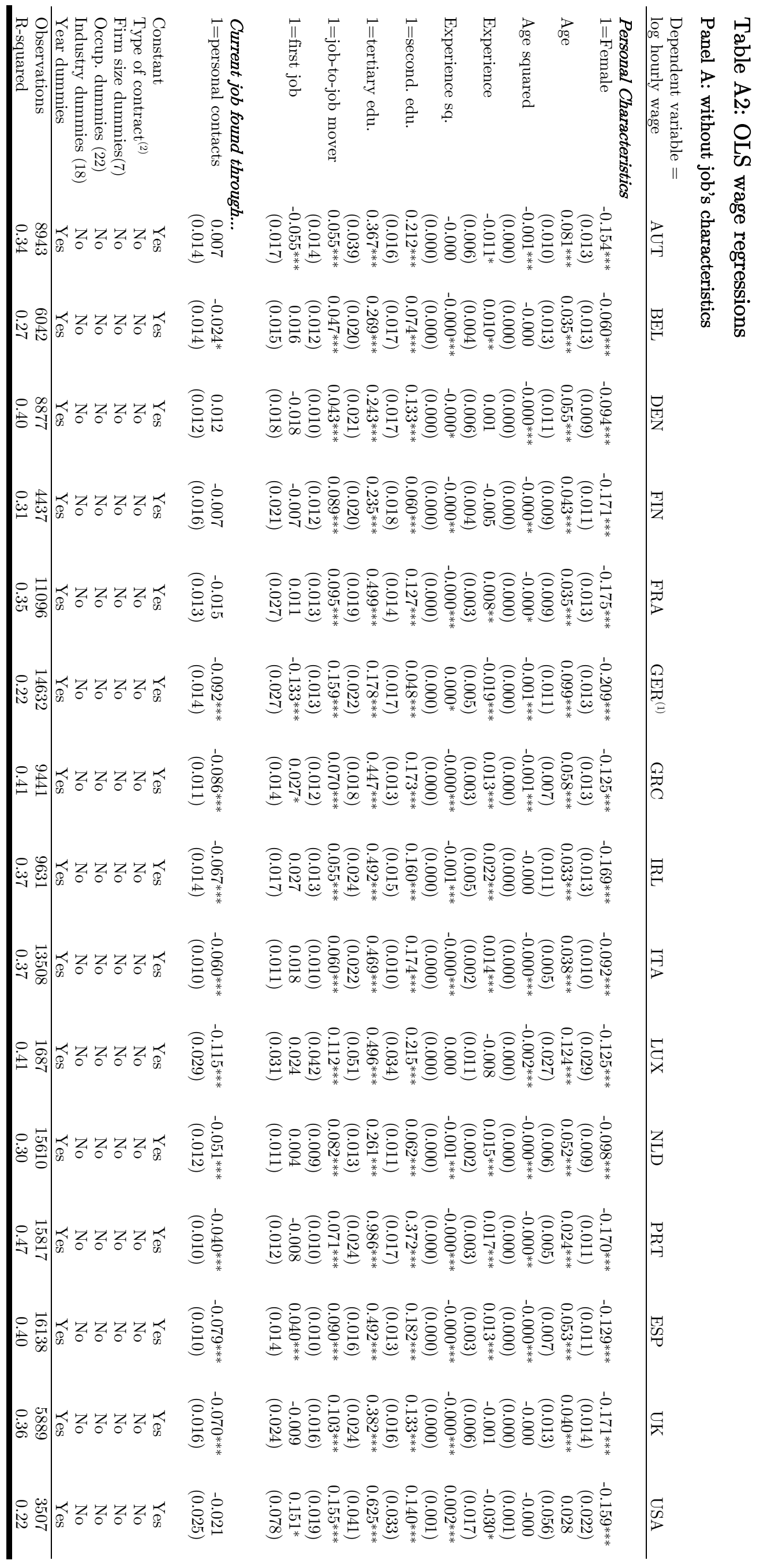




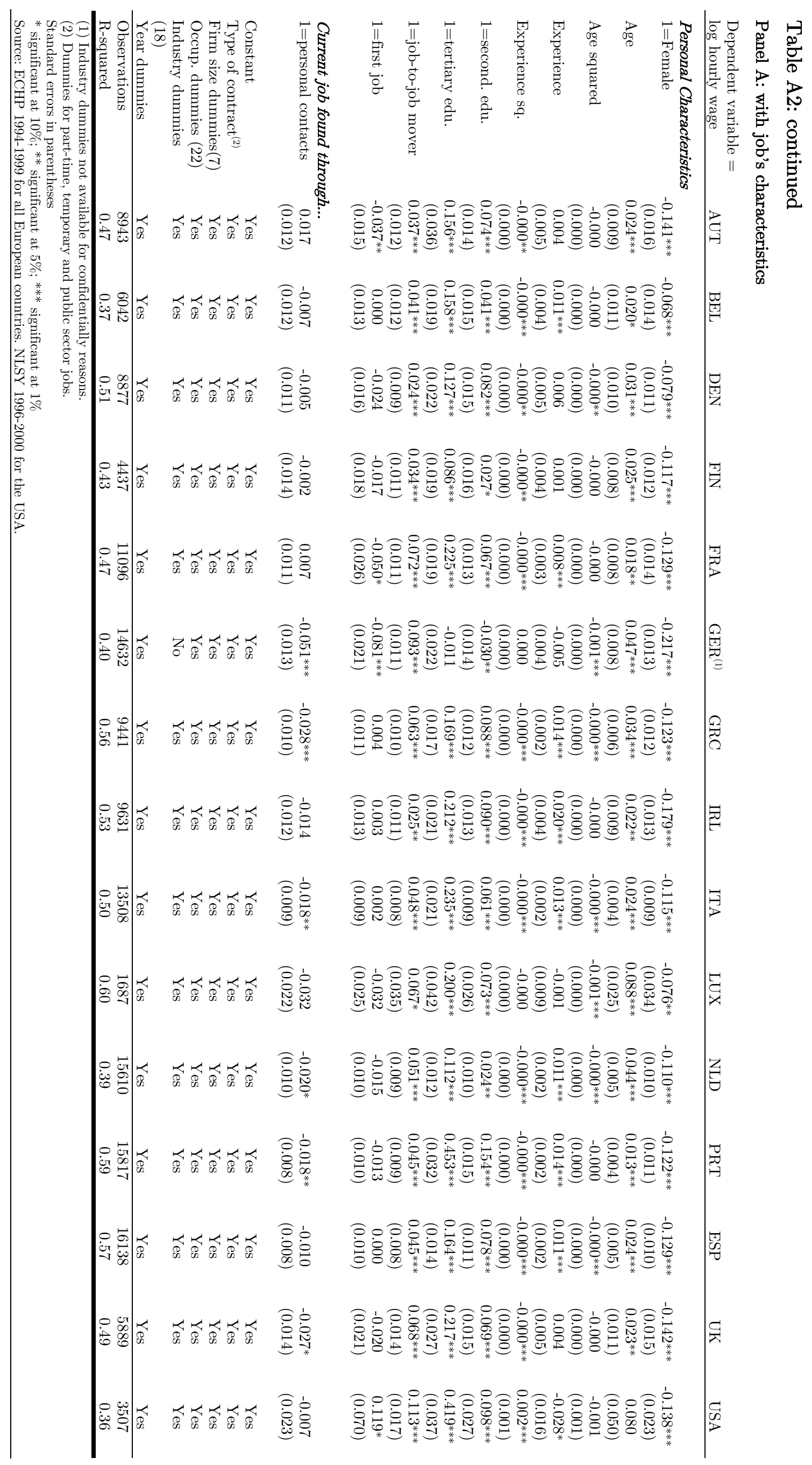




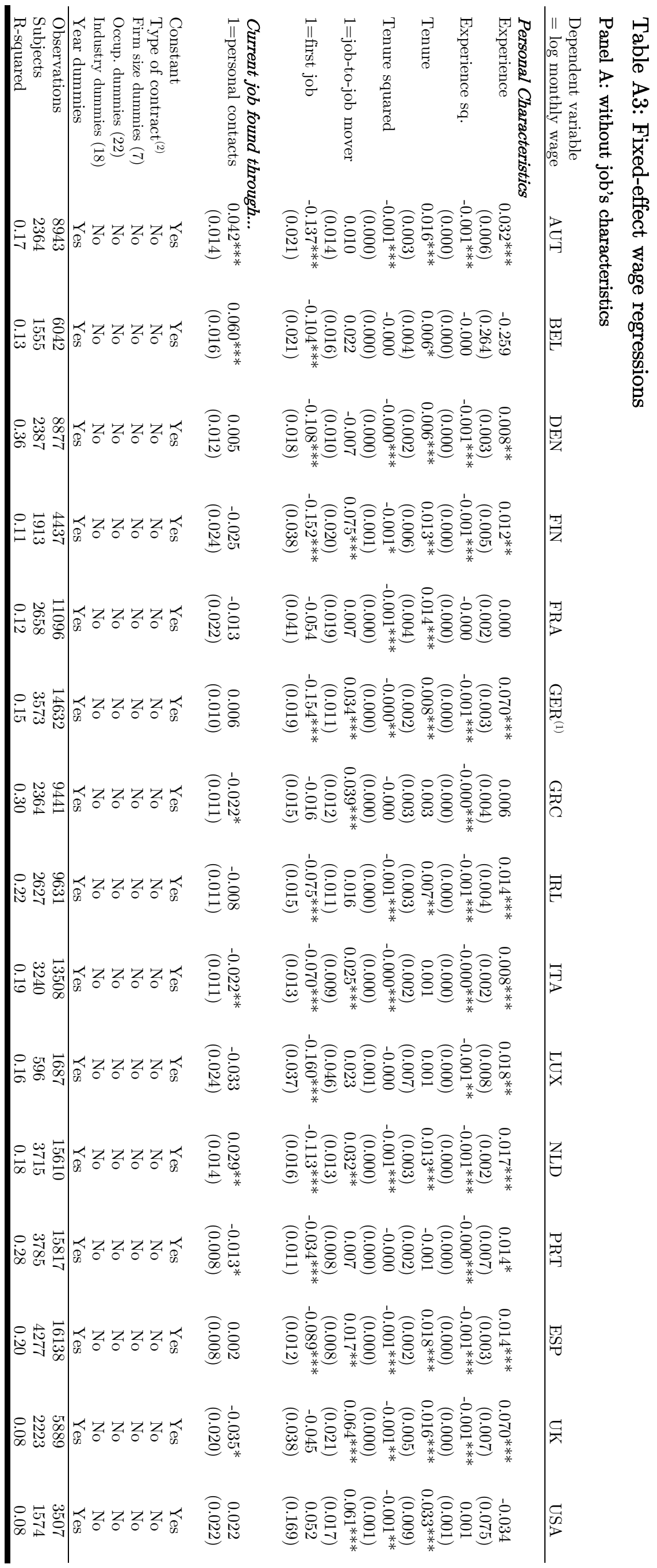




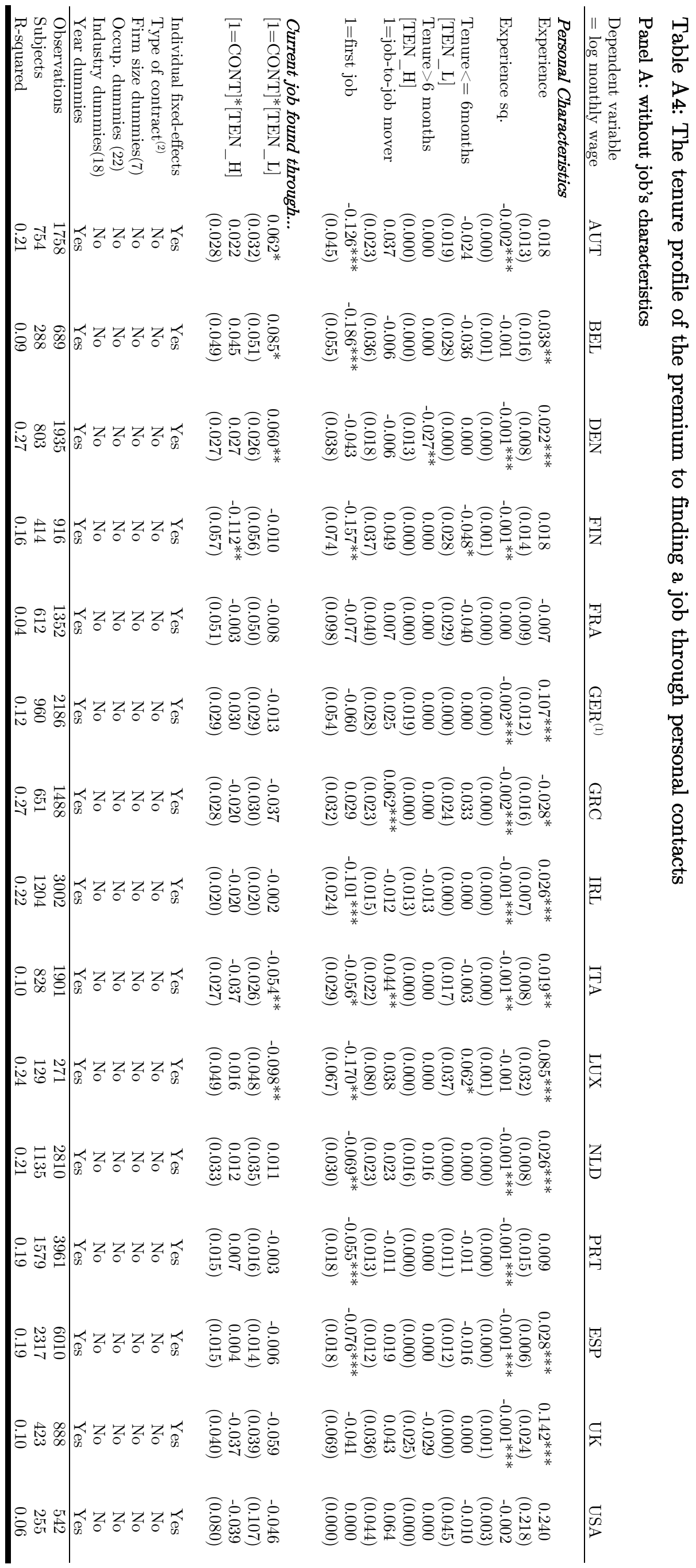




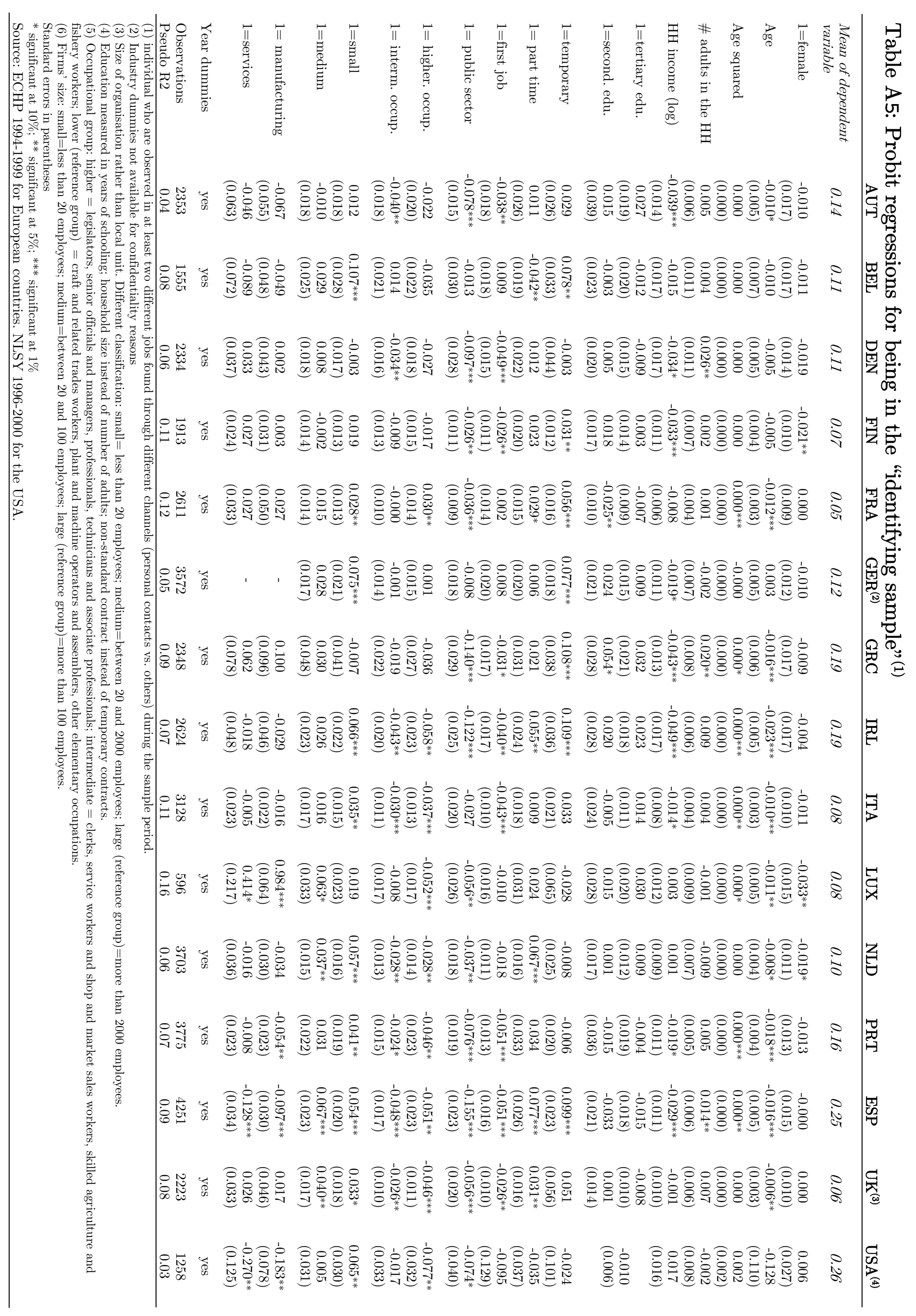




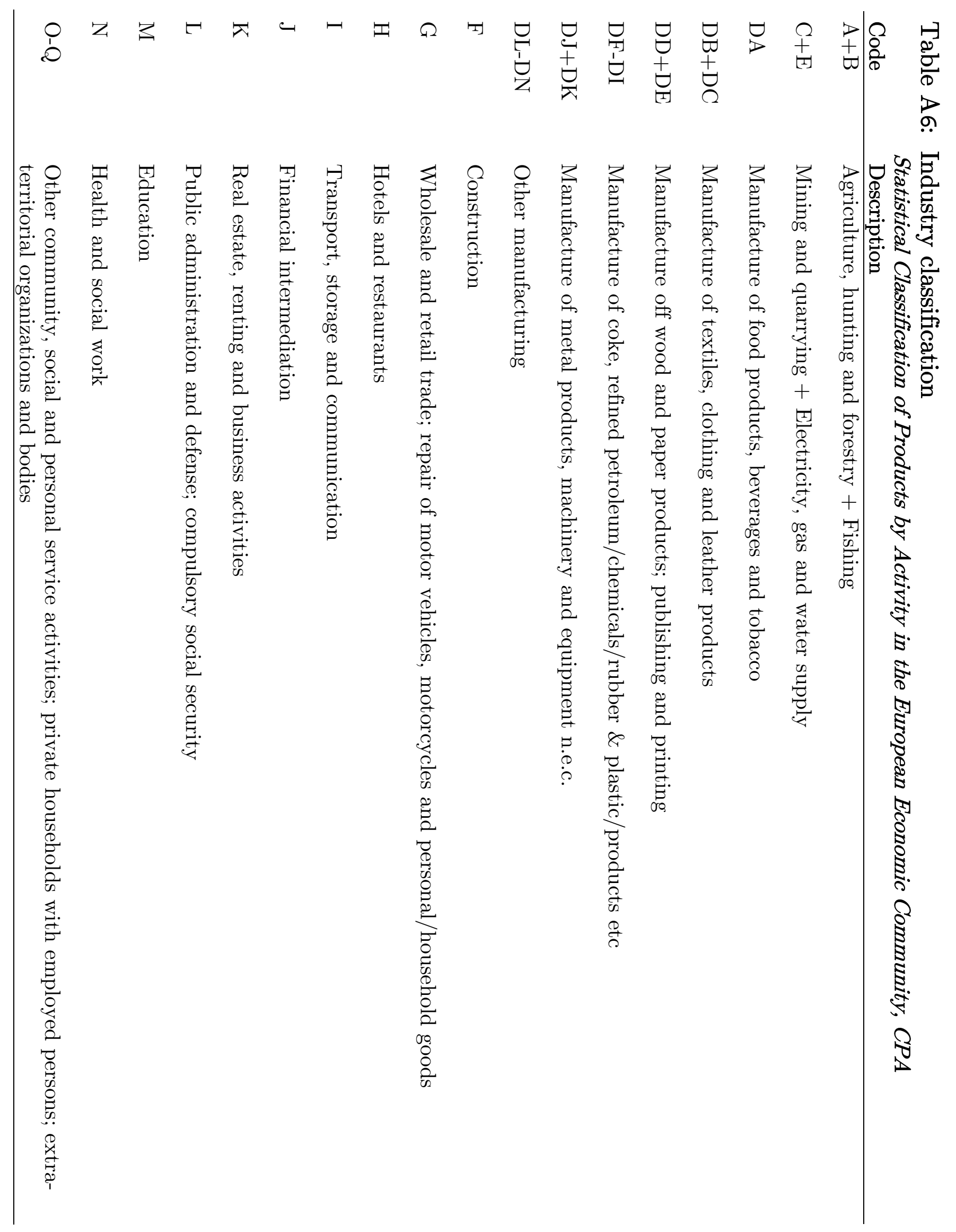




\section{References}

[1] Barron J. M., Bishop J., Dunkelberg C. (1985), 'Employer Search: the Interviewing and Hiring of New Employees', The Review of Economics and Statistics, vol. 67(1), pp. 43-52.

[2] Barron J. M., Berger M. C., Black D. A. (1997), 'Employer Search, Training and Vacancy Duration', Economic Inquiry, 35(1), pp. 167-192.

[3] Bentolila S., Michelacci C., Suàrez J. (2003), 'Social Networks and Occupational Choice', CEMFI, mimeo.

[4] Breaugh J. A., Mann R. B. (1984), 'Recruiting Source Effects: a Test of Two Alternative Explanations', Journal of Occupational Psychology, 57, pp. 261-267.

[5] Bull C., Ornati O., Tedeschi P. (1987), 'Search, Hiring Strategies, and Labor Market Intermediaries', Journal of Labor Economics, 5(4), pp. S1-S17.

[6] Cahuc P., Fontaine F. (2002), 'On the Efficiency of Job-Search with Social Networks', CEPR Discussion Paper n. 3511.

[7] Calvò-Armengol A., Zenou Y. (2001), 'Job Matching, Social Networks and Word-of-Mouth Communication', CEPR Discussion Paper Series 2797.

[8] Calvò-Armengol A. (2002), 'Job Contact Networks', Journal of Economic Theory, forthcoming.

[9] Calvò-Armengol A., Jackson M. O. (2002), 'The Effect of Social Networks on Employment and Inequality', American Economic Review, forthcoming.

[10] Corcoran M., Datcher L., Duncan G. (1980), 'Information and Influence Networks in Labor Markets', in G. Duncan and J.N. Morgan (eds.), Five Thousand American Families - Patterns of Economic Progress, Vol. 8, Ann Arbor, Mich.: Institute of Social Research.

[11] Fernandez R. M., Castilla E. J., Moore P. (2000), 'Social Capital at Work: Networks and Employment at a Phone Center', American Journal of Sociology, 105(5), pp. 1288-1356.

[12] Gautier P. A. (2002), 'Non-sequential Search, Screening Externalities and the Public Good Role of Recruitment Offices', Economic Modelling, 19(2), pp. 179-196. 
[13] Gorter C., Nijkamp P., Rietveld P. (1996), 'Employers' Recruitment Behavior and Vacancy Duration: an Empirical Analysis for the Dutch Labour Market', Applied Economics, 28, pp. 1463-1474.

[14] Gorter C., Russo G., Shettkat R. (2001), ‘Searching, Hiring and Labour Market Conditions’, Labour Economics, 8(5), pp. 553-571.

[15] Gorter C., Van Ommeren J. (1999), 'Sequencing, Timing and Filling Rates of Recruitment Channels', Applied Economics, 31(10), 1149-1160.

[16] Granovetter M. (1974), Getting A Job, University of Chicago Press.

[17] Holzer J. (1987a), 'Hiring Procedures in the Firm: Their Economic Determinants and Outcomes', NBER Working Paper n. 2185.

[18] Holzer H. (1987b), 'Informal Job Search and Back Youth Unemployment', American Economics Review, 77(3), 446-452.

[19] Holzer H. (1988), 'Search Method Use of Unemployed Youth', Journal of Labor Economics, 6(2),120.

[20] Kugler A. (1997), 'Employee Referrals and the Inter-Industry Wage Structure', Working Paper 252, Universitat Pompeu Fabra, Department of Economics.

[21] Kugler A. (2003), 'Employee Referrals and Efficiency Wages', Labour Economics, 10(5), 531-556.

[22] Lindeboom M., Van Ours J., Renes G. (1994), 'Matching Employers and Workers: an Empirical Analysis on the Effectiveness of Search', Oxford Economic Papers, 46(1), 45-67.

[23] Manning A. (1999), 'Pretty vacant: recruitment in Low-Wage Labour Markets', Discussion Paper n.418, Centre for Economic Performance, London School of Economics.

[24] Margolis D. N., Simonnet V. (2003), 'Educational Track, Networks and Labour Market Outcomes', Discussion Paper n.699, Institute for the Study of Labor (IZA).

[25] Marmaros D., Sacerdote B. (2002), 'Peer and Social Networks in Job Search', European Economic Review, 46(4-5), 870-879. 
[26] Montgomery, J. (1991), 'Social Networks and Labor Market Outcomes', American Economic Review, 81(5), 1408-1418.

[27] Mortensen D., Vishwanath T. (1994), 'Personal Contacts and Earnings. It is who you know!', Labour Economics, 1(2), 187-201.

[28] Mouw T. (2002), 'Social Capital and Job Search: Do Contacts Matter?', University of North Carolina, mimeo.

[29] Osberg L. (1993), 'Fishing in different pools: Job-Search Strategies and Job-Finding Success in Canada in Early 1980s', Journal of Labor Economics, 11(2), 348-386.

[30] Peracchi F. (2002), 'The European Community Household Panel: A review', Empirical Economics, 27(1), 63-90.

[31] Petersen T., Saporta I., Seidel M. L. (2000), 'Offering a Job: Meritocracy and Social Networks', American Journal of Sociology, 106(3), 763-816.

[32] Pissarides C. (2000), Equilibrium Unemployment Theory, MIT Press.

[33] Pistaferri L. (1999), 'Informal Networks in the Italian Labor Market', Giornale degli Economisti e Annali di Economia, 58(3-4), 355-375.

[34] Rees, A. (1966), 'Information Networks in Labor Markets', American Economics Review, 56(1/2), 559-566.

[35] Roper S. (1988), 'Recruitment Methods and Vacancy Duration', Scottish Journal of Political Economy, 35(1), 51-64.

[36] Saloner G. (1985), 'Old Boy Networks as Screening Mechanisms', Journal of Labor Economics, $3(3), 255-267$.

[37] Simon J.C., Warner T. (1992), 'Matchmaker, Matchmaker: the Effect of Old Boy Networks on Job Match Quality, Earnings and Tenure', Journal of Labor Economics, 1093), 306-330.

[38] Staiger D. (1990), 'The Effect of Connections on the Wages and Mobility of Young Workers', PhD Thesis, Department of Economics, MIT, Cambridge, MA. 
[39] Wahba J., Zenou Y. (2002), 'Does Density Affect Social Networks? Theory and Application to Egypt', mimeo, University of Southampton, Economics Department. 


\section{CENTRE FOR ECONOMIC PERFORMANCE \\ Recent Discussion Papers}

622 Steven McIntosh

621 Steven McIntosh

620 David Marsden

619 Alan Manning

618 Mari Kangasniemi

L. Alan Winters

Simon Commander

617 Vicentre CuZat

Maria Guadalupe

616 James Harrigan

Anthony J. Venables

615 Howard Gospel

Paul Willman

614 Andrew B. Bernard

Stephen Redding

Peter K. Schott

Helen Simpson

613 David Marsden

612 David G. Blanchflower

Alex Bryson

611 Stephen Gibbons Stephen Machin
The Returns to Apprenticeship Training

The Impact of Vocational Qualifications on the Labour Market Outcomes of Low-Achieving SchoolLeavers

The 'Network Economy' and Models of the Employment Contract: Psychological, Economic and Legal

Instrumental Variables for Binary Treatments with Heterogeneous Treatment Effects: A Simple Exposition

Is the Medical Brain Drain Beneficial? Evidence from Overseas Doctors in the UK

Executive Compensation and Product Market Competition

Timelines, Trade and Agglomeration

Comparatively Open: Statutory Information Disclosure for Consultation and Bargaining in Germany, France and the UK

Relative Wage Variation and Industry Location

Unions and Procedural Justice: An Alternative to the Common Rule

The Union Wage Premium in the US and the UK

Valuing Rail Access Using Transport Innovation 
610 Johannes Hörner

L.Rachel Ngai

Claudia Olivetti

609 Nikolaus Wolf

608 Ellen E. Meade

David Stasavage

607 Ghazala Azmat

Maia Güell

Alan Manning

606 Henry G. Overman

L. Alan Winters

605 Stephen Machin

Stephen Wood

604 Maarten Goos

Alan Manning

603 Nan-Kuang Chen

Hsiao-Lei Chu

602 Ricardo Peccei

Helen Bewley

Howard Gospel

Paul Willman

601 Andy Charlwood

600 Christopher A. Pissarides
Public Enterprises and Labor Market Performance

Endowments, Market Potential, and Industrial Location: Evidence from Interwar Poland (1918-1939)

Publicity of Debate and the Incentive to Dissent: Evidence from the US Federal Reserve

Gender Gaps in Unemployment Rates in OECD Countries

The Geography of UK International Trade

Looking for HRM/Union Substitution: Evidence from British Workplaces

Lousy and Lovely Jobs: the Rising Polarization of Work in Britain

Collateral Value and Forbearance Lending

Is it Good To Talk? Information Disclosure and Organisational Performance in the UK Incorporating evidence submitted on the DTI discussion paper 'High Performance Workplaces Informing and Consulting Employees'

The Anatomy of Union Decline in Britain 1990-1998

Unemployment in Britain: A European Success Story

The Centre for Economic Performance Publications Unit

Tel 02079557673 Fax 02079557595 Email info@cep.lse.ac.uk Web site http://cep.lse.ac.uk 